\title{
Wood products and green chemistry
}

\author{
Antonio Pizzi
}

Received: 7 September 2014 / Accepted: 18 December 2014 /Published online: 22 January 2015

(C) The Author(s) 2015. This article is published with open access at Springerlink.com

\begin{abstract}
- Key message Green chemistry for and from wood has developed numerous industrial products, namely biosourced, green wood adhesives and preservatives, foams, composite matrices, laminates, hard and flexible plastics, flexible films, and abrasive grinding discs, and their number is still growing.

- Introduction This review addresses (1) the elimination of toxic aldehydes from the most common wood panel adhesive, the one based on urea, itself a natural product, (2) biosourced adhesives derived from wood or other vegetable matter and used for wood products, and (3) wood and bark tannin-based foams, natural fiber composites using tannin matrices, paper surface laminates and continuous high-pressure paper laminates using tannin-furanics, hard plastics based on tanninfuranic materials and some of their applications, flexible biosourced tannin-furanic films, and biosourced wood preservatives.
\end{abstract}

Keywords Biosourced materials $\cdot$ Non-toxic $\cdot$

Environment-friendly · Adhesives · Composites · Foams ·

Paper laminates · Hard plastics · Abrasives · Flexible films ·

Wood preservatives

Handling Editor: Jean-Michel Leban

A. Pizzi $(\bowtie)$

LERMAB, University of Lorraine, Epinal, France

e-mail: antonio.pizzi@univ-lorraine.fr

A. Pizzi

Department of Physics, King Abdulaziz University, Jeddah, Saudi Arabia

\section{Introduction}

Green chemistry is a very wide field that encompasses such a variety of raw materials and products that a serious review on such a subject has forcefully to be partial to some more detailed aspects. Already, even to speak of green chemistry related to wood products and products derived from wood or for wood becomes a hard and vast task considering the ferment of ideas and work in this field going on now for quite a few years.

In this review, what will be dealt with will be (1) the elimination of toxic aldehydes from the most common wood panel adhesive, the one based on urea, itself a natural product, (2) biosourced adhesives derived from wood or other vegetable matter and used for wood products, and (3) tannin-based foams, natural fiber composites using tannin matrices, paper surface laminates and continuous high-pressure paper laminates using tannin-furanics, hard plastics based on tanninfuranic materials and some of their applications, flexible biosourced tannin-furanic films, and biosourced wood preservatives. Even to deal briefly with all these will still not give a complete image of such a vast field.

\section{Biosourced wood adhesives}

Wood products are the largest users of adhesives, wood adhesives constituting more than $65 \%$ by volume of all the adhesives used in the world. It is such large volume that renders hard the substitution of existing synthetic adhesives with some biosourced products, products possibly obtained from wood itself. For example, to substitute urea-formaldehyde (UF) adhesives, the worldwide consumption of which is of the order of 11 million tons resin solids per year, is perfectly possible but not really feasible in the short term. It is for this reason that this review will address first this aspect. 


\subsection{Urea, also a natural material for wood adhesives}

Urea is a natural raw material. It is also obtained industrially in enormous quantities by catalytic reaction of the oxygen and nitrogen of the air on glowing coals or other glowing carbon material, even charcoal or wood. The material to substitute, although even this can be of natural origin, is then formaldehyde, now classified toxic and oncogenic. It pays, seeing the volumes involved, to start concentrating to develop urea-based adhesives using aldehydes that are not toxic, nor volatile, but still maintaining the clear or white appearance of UF resins as such adhesives can be classified as natural too. While many approaches can be taken to develop urea-based adhesives in this manner, recently a first important success in the bonding of plywood with this approach has been achieved (Deng et al. 2014a). Resins based on urea-glyoxal for textiles are wellknown (Petersen 1968), but these are low condensation resins not adaptable for wood. Hybrid resins urea-formaldehydeanother aldehyde have been the initial target of several researchers, with good results for plywood (Deng et al. 2014b; Zhang et al. 2009, 2014). The problem of these is that formaldehyde, although much less, is still there. An old technology based on urea-furfural resins (Novotny and Johnson 1931) is not a good substitute for urea-formaldehyde not only for the lower reactivity but mainly for the dark color of the resin imparted by the condensation of furfural. Thus, the first truly urea adhesive for plywood without any formaldehyde has only recently been developed opening a new chapter on natural environment-friendly adhesives (Deng et al. 2014a).

The non-volatile and non-toxic aldehyde glyoxal (G) was used to substitute formaldehyde to react with urea (U) to synthesize a urea-glyoxal (UG) resin under weak acid conditions $(\mathrm{pH}=4-5)$. The strength of the bonded plywoods was tested, and the curing process of the UG resin was studied by dynamic mechanical analysis (DMA). Some initial acid-catalytic reactions involved in the synthesis of the UG resin were theoretically investigated by quantum chemistry using density function theory. Furthermore, the UG resin was characterized by matrix-assisted laser desorption ionization time-of-flight mass spectrometry (MALDI-TOF-MS). The results showed that the bonded plywood with dry shear strength of $0.98 \mathrm{MPa}$ could be directly used as interior decoration and furniture material without formaldehyde emission in dry conditions (Deng et al. 2014a). The results of DMA analysis indicate that the cured system has best mechanical properties within the range $138.4-182.4{ }^{\circ} \mathrm{C}$. The addition reaction of either $\mathrm{G}$ or $\mathrm{G} 1$ (these being two different forms of protonated glyoxal) with $U$ goes through a mechanism represented by a four-member ring transition state with a notable barrier (above $130 \mathrm{~kJ} / \mathrm{mol}$ ). On the other hand, the reactions of $U$ with different protonated forms of glyoxal ( $\mathrm{p}-\mathrm{G}$ and $\mathrm{p}-\mathrm{G} 1$ ) have two main pathways to form two important carbocation reactive intermediates of C-p-UG and C-p-UG1 with lower energy barriers of $30 \sim 40 \mathrm{~kJ} / \mathrm{mol}$. With the mediation of a water molecule, the intramolecular proton transfer processes occur easily. The main assignments of MALDI-TOF-MS of the UG resin correspond to the intermediate products of $\mathrm{C}-\mathrm{p}-\mathrm{UG} 1$, C-p-UG, UG1, and UG oligomers or coreactions between each other, further confirming the reaction mechanism proposed by quantum chemical calculation. Namely MALDITOF-MS results were quite compatible with quantum chemical calculations, and these results confirmed each other theoretically as well as experimentally.

It is likely that such type of approach to urea-based resins can be expanded in the future using other aldehydes, but it can constitute a major line of investigation in the short to medium term as regards biosourced adhesives.

\subsection{Other "natural" wood adhesives}

\subsubsection{Tannin adhesives}

Tannin cross-linking by formaldehyde in a polycondensation reaction is the traditional way for tannins to function as exterior grade weather-resistant wood adhesives. Tannin reactions are based on their phenolic character similar to those of phenol with formaldehyde. These adhesives have already been used industrially in the past and still now for many years (CSR Wood Panels, Oberon, Australia; Bisonboard, Piet Retief, South Africa; Novobord, Port Elisabeth, South Africa; Sekisui Chemical Co., Japan; Masisa, Chiguayante, Chile; Zimbord, Mutare, Zimbabwe), and their use with procyanidin tannin species present everywhere, such as tannins from pine bark and other softwood tree species widely diffuse around the world, holds considerable promise for their future use expansion. Formaldehyde is however the problem here too. Extensive reviews on the classical technologies of these adhesives already exist (Pizzi 1994a).

The quest to decrease or completely eliminate formaldehyde emissions from wood panels bonded with adhesives, although not really necessary in tannin adhesives due to their very low emission (as most phenolic adhesives), has nonetheless promoted some research to further improve formaldehyde emission or to simply totally eliminate formaldehyde. This has centered on two lines of investigation: (i) the use of hardeners not emitting at all simply because either no aldehyde has been added to the tannin, or because the aldehyde cannot be liberated from the system, and (ii) tannin autocondensation. Methylolated nitroparaffins, such and in particular the simpler and least expensive exponent of their class, namely trishydroxymethyl nitromethane (Trosa and Pizzi 2001), belong to the first class. They function well, but they are too expensive. A cheaper but as equally effective alternative to hydroxymethylated nitroparaffins is the use of hexamine as a tannin hardener. Tannin-hexamine adhesives are already commercial. Under many wood adhesive application conditions, 
contrary to what was thought for many years in the past, hexamine used as a hardener of a fast reacting species is not at all a formaldehyde-yielding compound, yielding extremely low formaldehyde emissions in bonded wood joints (Pizzi 1978, 1994a, b). ${ }^{13} \mathrm{C}$ NMR evidence has confirmed (Kamoun and Pizzi 2000; Kamoun et al. 2003; Pichelin et al. 1999a, Pichelin 1999b) that the main decomposition (and recomposition) mechanism of hexamine under such conditions is not directly to formaldehyde. It rather proceeds through reactive intermediates. Some industrial applications have already been obtained (Pichelin et al. 2006; Valenzuela et al. 2012).

On this basis, the use of hexamine as a hardener of a tannin, hence a tannin-hexamine adhesive, is a very environmentally friendly proposition. Formaldehyde emissions in a great chamber have been proved to be so low to be limited exclusively to what is generated by the wood itself, hence truly E0 panels (panels with no emission of formaldehyde whatsoever). The panels obtained with tannin-hexamine adhesives, according to under which conditions they are manufactured, can satisfy both interior and exterior grade standard specification requirements (Pizzi 1978; Pizzi et al. 1996; Pichelin et al. 1999). Steam injection presses recently have shown to be better suited to give better results for exterior grade boards using tannin-hexamine adhesives. Comparable results are obtained with pine tannins or other procyanidins hardened with hexamine (Pizzi et al. 1994; Valenzuela et al. 2012). In the same reference, catalysis of the reaction in the presence of small amounts of accelerators such as a zinc salt allows even better results or faster press times. Of particular interest have been the developments in pine tannin adhesives, this being valid for all procyanidin/prodelphinidin tannins such as raisin mar derivatives, spruce, etc., for a number of adhesive applications (Ballerini et al. 2005; Zhou and Pizzi 2014) such as plywood, particleboard, and other panels, some coupled with the non-toxic, non-volatile aldehyde glyoxal.

\subsection{Hardening by tannin autocondensation}

The autocondensation reactions characteristic of polyflavonoid tannins have only recently been used to prepare adhesive polycondensate hardening in the absence of aldehydes (Meikleham et al. 1994). Although this reaction may lead to considerable increases in viscosity, gelling does not generally occur. However, gelling takes place when the reaction occurs (i) in presence of small amounts of dissolved silica (silicic acid or silicates) catalyst and some other catalysts (Pizzi and Meikleham 1995; Pizzi et al. 1995a, b) and (ii) on a lignocellulosic surface. In the case of the more reactive procyanidins and prodelphinidin type tannins, such as pine tannin, cellulose catalysis is more than enough to cause hardening and to produce boards of strength satisfying the relevant standards for interior grade panels, while for slower reacting tannins, a catalyst such as silica is needed (Pizzi 1994a).
Autocondensation reactions have been shown to contribute considerably to the dry strength of wood panels bonded with tannins but to be relatively inconsequential in contributing to the bonded panels' exterior grade properties which are rather determined by polycondensation reactions with aldehydes (Garcia and Pizzi 1998a, b; Pizzi and Stephanou 1993a, b).

\subsection{Lignin adhesives}

Much has been written about and much research has been conducted in the use of lignins for wood panel adhesives. It can safely be said that this natural raw material has probably been the most intensely researched one as regards to wood adhesive application. Lignins are phenolic materials, are abundant, and of low cost, but they have lower reactivity towards formaldehyde, or other aldehydes, than even phenol. Extensive reviews on a number of proposed technologies of formulation and application do exist, and the reader is referred to these in earnest (Nimz 1983; Newman and Glasser 1985; Gardner and Sellers 1986; Shimatani et al. 1994; Calvé 1999; Viikari et al. 1999; Blanchet et al. 2000; Kim and Kim 2003; Lopez-Suevos and Riedl 2003). This field is however remarkable for how small has been the industrial success in using these materials. In general, lignin and lignosulfonates have been mixed in smaller proportions to synthetic resins, such as phenol-formaldehyde (PF) resins, and even UF resins, to decrease their cost. Their low reactivity and lower level of reactive sites, however, conjure that for any percentage of lignin added, the cost advantage is abundantly lost in the lengthening of the panel pressing time this causes. The only step forward that has found industrial application in the last 20 years is to prereact in a reactor lignin with formaldehyde to form methylolated lignin, thus to do part of the reaction with formaldehyde first, and then add this methylolated lignin to PF resins at the 20 to $30 \%$ level (Gardner and Sellers 1986; Calvé 1999). The lignin used for this application is generally alkali lignin. Lignosulfonates cannot be used in general due to the solubilizing and water-attracting characteristics of the abundant sulfonic groups, thus impairing the water resistance of panels and glue lines. These resins have been used in some North American plywood mills. Particularly in plywood mills, because the pressing time is not the factor determining the output rate of the factory, one can afford to use relatively long press times with good results.

None of the many adhesive systems based on pure lignin resins, hence without synthetic resin addition, has succeeded commercially at an industrial level. Some were tried industrially but for one reason or another, too long pressing time, high corrosiveness for the equipment, etc., they did not meet with commercial success. Still notable among these is the Nimz system based on the networking of lignin in presence of hydrogen peroxide (Nimz 1983; Nimz and Hitze 1980; Pizzi 1994a). Only one system is used successfully still today, but 
this only for high-density hardboard, in several mills worldwide. This is the Shen system, based on the self-coagulation and cross-linking of lignin by a strong mineral acid in the presence of some aluminum salt catalysts (Fung et al. 1977; Nimz 1983; Shen 1977, 1998). However, attempts to extend this system to the industrial manufacture of medium-density fiberboard (MDF) are known to have failed.

Of interest in the MDF field is also the system of adding laccase enzyme-activated lignin to the fibers or activating the lignin in situ, in the fibers also by enzyme treatment (Kharazipour et al. 1991, 1998) but this needed the addition of $1 \%$ isocyanate (polymeric 4'4'-diphenyl methane diisocyanate (PMDI) to the board to press at acceptably short press times, or by extending the pressing times to ridiculous lengths $(100-\mathrm{s} / \mathrm{mm}$ board thickness while industrial press times are of the order of 3to 7 -s/mm board thickness) (Felby et al. 1997). In the former case, an adhesive had to be used, with the same result obtained by pressing untreated hardboard, a 100-year-old process, hence just wasting expensive time and enzymes. The second case instead illustrates even more clearly where the problem lies and what breakthrough is necessary: enzyme-mobilizing lignin works but not fast enough. The breakthrough necessary is a new, strong catalyst of the enzymatic action capable of allowing pressing times of industrial significance. This has not been found, or even considered, as yet.

A promising new technology based on lignin use for wood adhesives is relatively recent and uses again premethylolated lignin in the presence of small amounts of a synthetic PF resin and PMDI (Newman and Glasser 1985; Pizzi and Stephanou 1993 c, d). Several types of lignins, namely softwood kraft, depolymerized softwood kraft, and organosolv wood and in particular grass lignins, can be used with this system, due to the boost to the system caused by the addition of the isocyanate. Partly depolymerized kraft lignins and organosolv grass lignins, thus lignins of lower average molecular mass, are best for this approach. The proportion of premethylolated lignin used is of $65 \%$ of the total adhesive, the balance being made up of $10-15 \%$ PF resin and of 20-25\% PMDI. The system is based on cross-linking caused by the simultaneous formation of methylene bridges and of urethane bridges, overcoming with the latter the need for higher cross-linking density that has been one of the problems which has stopped lignin utilization in the past. More interesting has been the recent development in which formaldehyde has been totally eliminated by substituting it with a non-toxic, non-volatile aldehyde, namely glyoxal (El Mansouri et al. 2007a, b). In these formulations, lignin is preglyoxalated in a reactor and the glyoxalated lignin obtained is mixed with tannin and with PMDI, eliminating thus the need of any formaldehyde or formaldehyde-based resins. This technology has been applied specifically by using wheat straw organosolv lignin, of particularly low number average molecular mass, and it is most likely usable to good effect for at least depolymerized softwood and hardwood kraft lignins. This technology has brought also to the total elimination of synthetic resins in the adhesive as described above, both technologies satisfying requirements for industrially significant pressing times.

A lot of a continuous flow of literature on the subject of lignin adhesives is just literature rehashing older systems all based on the substitution of some phenol in PF resins. In general, these papers do not seem to be aware of the slow pressing time problem, and they do not address it, perpetuating the myth of $\mathrm{PF} /$ lignin adhesives while repeating the same age-old errors. They lead new researchers in the field to believe they are doing something worthwhile with parameters that do not satisfy the requirements of press rate of the panel manufacturing industry.

Some new and rather promising technologies on lignin adhesives have, however, been developed recently. These are (a) adhesives for particleboard and other agglomerate wood panels based on a mix of tannin/hexamine with preglyoxalated lignin and (b) similar formulations for high resin content, high-performance agricultural fiber composites.

Mixed interior wood panel tannin adhesive formulations were developed in which lignin is in considerable proportion, $50 \%$, of the wood panel binder and in which no "fortification" with synthetic resins, such as the isocyanates and phenolformaldehyde resins as used in the past, was necessary to obtain results satisfying relevant standards. The wood panel itself is constituted of $99.5 \%$ natural materials, the $0.5 \%$ balance being composed of glyoxal, a non-toxic and nonvolatile aldehyde, for the preglyoxalation of lignin and of hexamine already accepted as a non-formaldehyde-yielding compound when in presence of a condensed tannin. Both particleboard and two types of plywood were shown to pass the relevant interior standards with such adhesive formulations (El Mansouri et al. 2007b; Mansouri et al. 2011a; Navarrete et al. 2012). The mechanism of copolymerization and hardening can be understood from Fig. 1.

\subsection{Protein adhesives}

Intense research induced by the sponsorship of the US United Soybean Board has revised interest in protein adhesives, soya protein primarily, but also others.

Soya and even gluten adhesives instead are definitely new. Both addition to traditional synthetic wood adhesives as well as their use as panel adhesives after partial hydrolysis and modifications have been reported, with acceptable results (Hettiarachy et al. 1995). These products are not widely used industrially/commercially as yet, but one industrial user has been reported in the USA.

Different technologies can be distinguished: First, technologies that are based on the prereaction of soy protein hydrolysate prereacted with formaldehyde and this preformilated soy protein being mixed with a PF resin and with isocyanate 
Fig. 1 Schematic path of the simultaneous coreactions of glyoxalated lignin with the tannin/hexamine adhesive system

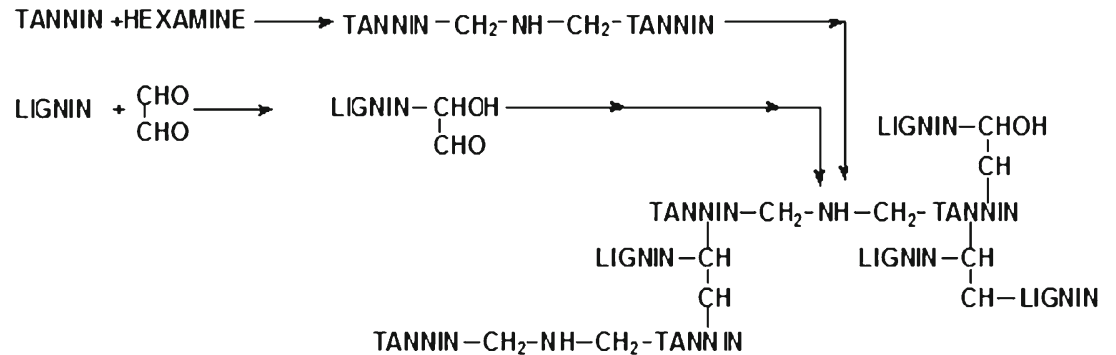

(PMDI) (Lorenz et al. 2006; Wescott et al. 2006), thus an identical technological approach to what already presented for lignin adhesives.

Second is the evolution of this technology, again along similar lines as for lignin, in which preglyoxalated soy protein or even soy flour or glyoxalated gluten protein hydrolysate, glyoxal being a non-volatile, non-toxic aldehyde, composes the glue mix with either a PF resin or with a flavonoid tannin the whole been added of 20-25\% isocyanate (PMDI) (Amaral-Labat et al. 2008; Lei et al. 2010; Lagel et al. $2014 \mathrm{a}, \mathrm{c})$. Both these systems work well.

A third system is based on the prereaction of the soy protein hydrolysate with maleic anhydride to form an adduct that is then reacted in the panel with polyethyleneimine (Liu and $\mathrm{Li}$ 2002, 2007; Zhong et al. 2003). The system works well, as one plywood company (Columbia Forest Products, Klamath Falls, Oregon) has started using it industrially in the USA but suffers of the drawback of too slow a press time, thus only usable for plywood, and to be excessively expensive, the price quoted being considerably higher than those of isocyanates. The use of epichloridrin too in this system renders it rather less acceptable from the point of view of the toxicity of the raw materials. A new system in which epichloridrin has been eliminated and substituted with a non-toxic material has been recently presented too (Jang and Li 2013).

Lastly, very recently, the addition/coreaction of 10-15\% proteins to UF resins by an international adhesive company to yield the Aswood range of commercial adhesives and the successful coreaction and substitution of $30 \%$ gluten protein hydrolysates in PF resins has led to lighter boards of very low formaldehyde emission and respecting the need for fast pressing times (Lagel et al. 2014a; Pizzi et al. 2013a.

\subsection{Carbohydrate adhesives and furanic resins}

Carbohydrates in the form of polysaccharides, gums, oligomers, and monomeric sugars have been employed in adhesive formulations for many years. Carbohydrates can be used as wood panel adhesives in three main ways: (i) as modifiers of existing PF and UF adhesives, (ii) by forming degradation compounds which then can be used as adhesives building blocks, and (iii) directly as wood adhesives. The second route above leads to furanic resins. Furanic resins, notwithstanding that their basic building blocks, furfuraldehyde and furfuryl alcohol, are derived from the acid treatment of the carbohydrates in waste vegetable material, are considered today, wrongly, as purely synthetic resins. This opinion might need to change as in reality they are real natural-derived resins and extensively used for many years in foundry core binders, with other uses such as wood preservation also becoming topical. Appropriate reviews just dedicated to them do exist (Belgacem and Gandini 2003). However, both compounds are relatively expensive and very dark-colored, but furanic resins have made their industrial mark in fields where their high cost is not a disadvantage. They can be used very successfully for panel adhesives, and they are used very successfully in other fields (as foundry core binders).

The use of carbohydrates directly dissolved in strong alkali as wood panel adhesives is not a new concept but is an interesting and a topical one to this day. All sorts of agricultural cellulosic materials have been successfully adapted to this technology, and the technology and its application have been extensively reported in the past (Chen 1996).

Research on the first route has centered particularly on the substitution of carbohydrates for parts of PF resins. It has been reported that at laboratory level, up to 50 to $55 \%$ of phenol in a PF resin can be substituted with a variety of carbohydrates, from glucose to polymeric, tree-derived hemicelluloses (Conner et al. 1986, 1989; Shen 1998; Trosa and Pizzi 1998). Apparently reducing sugars could not be used directly as they are degraded to saccharinic acids under the acid conditions required in the formulation of the resin. Reducing sugars can be used to successfully modify PF resins if they are reduced to the corresponding alditols or converted to glycosides. Some carbohydrates appeared to be incorporated into the resin network mainly through ether bridges. Generally, the resin is prepared by coreacting phenol, the carbohydrate in high proportion, a lower amount of urea, and formaldehyde. Extensive and rather successful industrial trials of this resin have also been reported (Trosa and Pizzi 1998).

Carbohydrate-based adhesives in which the formulation starts with the carbohydrate itself have also been reported, but the acid system used during formulation readily degrades the original carbohydrate to furan intermediates which then polymerize. An interesting concept that was advanced early on in carbohydrate adhesive research was the conversion of 
the carbohydrate to furanic products in situ, which then homopolymerize as well as react with the lignin in wood.

Several research groups (Alma et al. 1996, 1998; Conner et al. 1986, 1989) have described the use of liquefied products from cellulosic materials, literally liquefied wood, which showed good wood adhesive properties. Lignocellulosic and cellulosic materials were liquefied in presence of sulfuric acid under normal pressure using either phenol or ethylene glycol. The cellulosic component in wood was found to lose its pyranose ring structure when liquefied. The liquefied product contains phenolic groups when phenol is used for liquefaction. In the case of ethylene glycol liquefaction, glucosides were observed at the initial stage of liquefaction and levulinates after complete liquefaction.

\subsection{Unsaturated oil adhesives}

Unsaturated vegetable oils are now widely available as a bulk commodity for a variety of purposes and at very acceptable prices. All resin research to date has focused on oils that contain at least one double bond. The majority of these technologies are not applied to wood and wood composite adhesives, but they can be translated eventually to this field. An excellent and detailed review of formulations and technology on the subject already exists (Wool and Sun 2005).

Until fairly recently, only two examples could be found in the literature where seed oil derivatives were being employed as wood adhesives. Linseed oil, for example, has been used to prepare a resin that can be used as an adhesive or surface-coating material (Tomkinson 2002; Miller and Shonfeld 2002). The chemistry of this resin centers on an epoxidation of the oil double bonds followed by cross-linking with a cyclic polycarboxylic acid anhydride to build up molecular weight. The reaction is started by the addition of a small amount of polycarboxilic acid.

When the epoxidized oil resin was evaluated as a wood adhesive in composite panels, it could be tightly controlled through the appropriate selection of triglycerides and polycarboxylic anhydrides. This apparently enables a wide range of materials with quite different features to be manufactured. The use as wood adhesives is one among the many uses, the focus of the development being more on plastic materials. The literature states that this plastic is well suited for use as a formaldehyde-free binder for wood fibers and wood particles including fibers and chips from cereal residues, such as straw and fiber mats.

The literature on this resin (Miller and Shonfeld 2002) claims that cross-linking can be varied through the addition of specialized catalysts, and several samples were prepared at a range of temperatures $\left(120-180{ }^{\circ} \mathrm{C}\right)$ that exhibited high water tolerance even at elevated temperatures, but no actual test data were included. Since this resin of reference, research in a number of other countries by imitators has produced very similar epoxidized oil resins. These are suitable for a number of applications, but the writer has tested one or two of them finding that for wood adhesive application, these resins have three major defects: (i) their hot-pressing time is far too slow to be of any interest in wood panel products, with the exception perhaps of plywood (for which they have not been tried), (ii) they are relatively expensive, and finally (iii) their environmental profile is rather unfavorable Cornillet et al. 2012). Unless the slow hot-pressing problem is overcome, and at a reasonable price, these resins will remain at the stage of potential interest. There is no doubt that these resins can be of interest in other fields, but it is symptomatic that no industrial use for wood panel adhesives has been reported as yet or is known to have occurred.

Bioresins based on soy bean and other oils have been developed also by other groups, mainly for replacement of polyester resins (Wool et al. 1998). These liquid resins were obtained from plant and animal triglycerides by suitably functionalizing the triglyceride with chemical groups (e.g., epoxy, carboxyl, hydroxyl, vinyl, amine, etc.) that render it polymerisable. The reference claims that excellent inexpensive composites were made using natural fibers such as hemp, straw, flax, and wood in fiber, particle and flake form. Those soy oil-based resins have a strong affinity for natural fibers and form a good fiber-matrix interface as determined by scanning electron microscopy of fractured composites. The reference also stated that these resins can be viewed as candidate replacements for phenol-formaldehyde, urethane, and other petroleum-based binders in particleboard, MDF, OSB, and other panel types. However, no actual test data has been supplied, and no industrial use in wood panel adhesives has actually been reported as yet.

Cashew nut shell liquid, mainly composed of cardanol but containing also other compounds (Fig. 4), is an interesting candidate for wood-based resins. Its dual nature, phenolic nuclei + unsaturated fatty acid chain, makes a potential natural raw material for the synthesis of waterresistant resins and polymers. Cardanol resins are known from the past, but their use has not been very diffuse simply because the raw material itself was rather expensive. The price however appears to be more affordable now since the extensive cashew nut plantations in Mozambique are in production.

The phenol, often resorcinol, group and/or double bonds in the chain can be directly used to form hardened networks. Alternatively, more suitable functional groups 
such as aldehyde groups and others can be generated on the alkenyl chain. Generally, modifications of this kind take several reaction steps, rendering the process too expensive for commercial exploitation in wood adhesives.

However, the Biocomposite Center in Wales has developed a system of ozonolysis in industrial methylated spirit (Bailey 1978; Tomkinson 2002) through which an aldehyde function is generated on the alkenyl chain of cardanol. The first reaction step yields as major product a cardanol hydroperoxide that following reduction by glucose or by zinc/acetic acid yields a high proportion of cardanol-derived aldehyde groups. These cross-link with the aromatic groups of cardanol itself, thus a self-condensation of the system yielding hardened networks (Fig. 2).

Exploratory laboratory particle board and lap shear bonding yielded good results. Nonetheless, neither the press times used nor other essential conditions that could help to evaluate the economical feasibility of these products were reported (Tomkinson 2002). Recently, a similar approach was used to make resins based on the ozonolysis of an unsaturated oil such as sunflower oil and by coreacting the non-volatile long chain aldehyde prepared with a flavonoid tannin (Thebault et al. 2013). The results obtained were comparable to those obtained with the cardanol ozonolysis technique but using more commonly available materials.

More recently, alternative and very encouraging techniques involving unsaturated oils for wood and wood fiber adhesives have come to the fore (Tasooji et al. 2010). Wheat straw particleboards were made using UF and acrylic-epoxidized soy oil (AESO) resins with two resin content levels, 8 and $13 \%$, and three pressing times, 8,10 , and $12 \mathrm{~min}$. The boards' physical and mechanical properties showed that AESO-bonded particleboards have higher physical and mechanical properties than UF-bonded boards, special in internal bonding and thickness swelling (Tasooji et al. 2010). This work was based on a number of different technologies presented and discussed in a most appropriate monograph (Wool and Sun 2005).

\section{Natural fibers/natural matrix high tech laminates and impregnated paper laminates}

Composites of good performance formed from non-woven mats of flax and hemp fibers and natural resin matrices have been prepared (Fig. 3). Both higher density thin composites as well as lower density thicker composites have been prepared (Nicollin et al. 2013a; Pizzi et al. 2009; Sauget and Pizzi 2014; Sauget et al. 2014). Three natural matrices types were used: (i) commercial mimosa flavonoid tannin extract with $5 \%$ hexamine added as hardener and (ii) a mix of mimosa or quebracho tannin + hexamine with glyoxalated organosolv lignin of low molecular weight, these two resins mixed $50 / 50$ by solids content weight, and (iii) mimosa tannin-resorcinol-aldehyde cold-set resins already commercial and described for glulam/ fingerjointing (Pizzi 1978, 1994a; Mansouri et al. 2009a) in which the aldehydes tried successfully were either formaldehyde, glutaraldehyde, or glyoxal, with equal success (Sauget et al. 2013). MOEs, thermomechanical analysis, Brinell surface

Fig. 2 Cardanol-based adhesive system
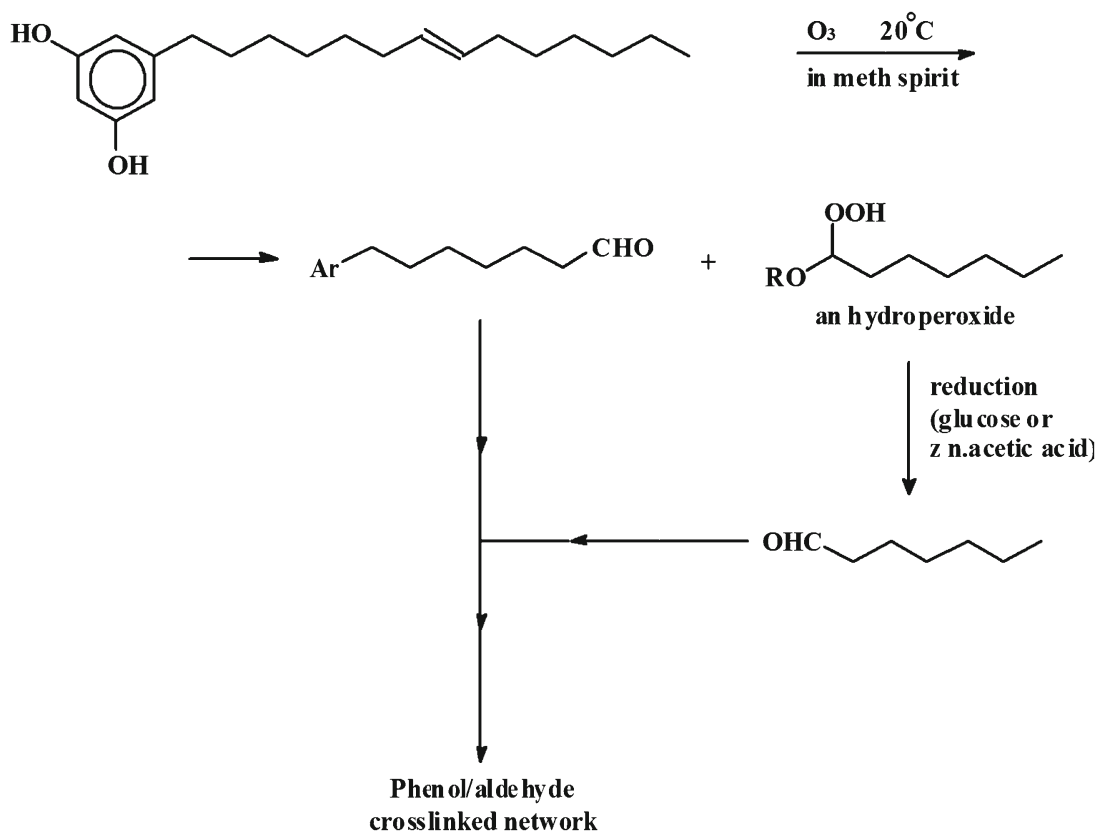


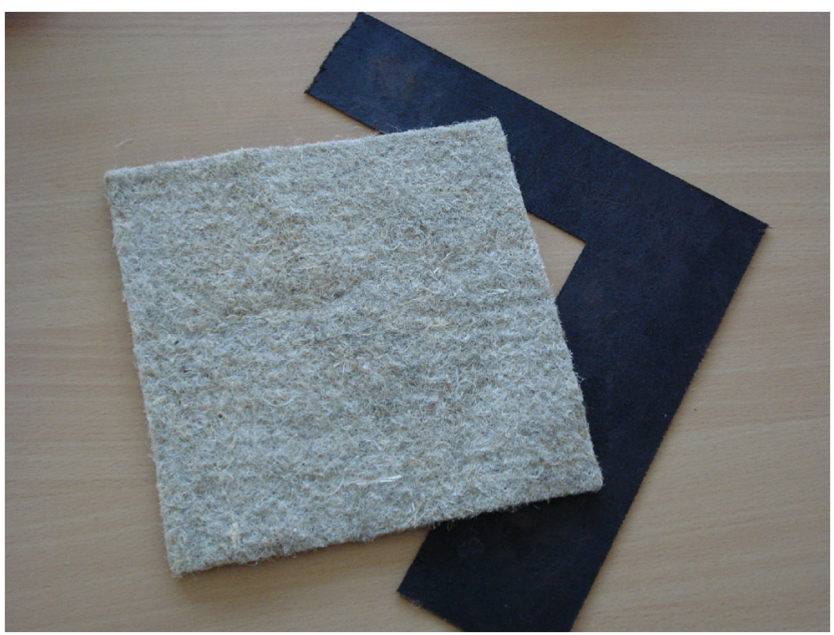

Fig. 3 Example of hemp non-woven mat and of the high resin composite produced by impregnating it with a tannin-based resin

hardness, and contact angle tests were carried out with good results. The composites made with the mix of tannin and lignin resins as a matrix remained thermoplastic after a first pressing. The flat sheets prepared after the first pressing were then thermoformed into the shape wanted. The composites made instead of tannin + hexamine alone or with the tanninresorcinol cold-set resin were instead directly thermosetting at the first hot-pressing.

Equally strong paper laminates based on paper impregnation with tannin-furanic resins have yielded paper-impregnated surface covering for panels and high-pressure paper laminates of performance and resistance superior to melamine resin-impregnated papers and comparable to phenolic resin-impregnated papers (Abdullah et al. 2013a, b). The same biosourced matrix was used to prepare multilayer paper-impregnated highpressure continuous laminates of good mechanical performance.

\section{Hard plastics and flexible films from wood and bark extractives and some of their applications}

A new $100 \%$ biosourced thermosetting plastic material, composed of condensed tannin/furanic thermoset, has been prepared and characterized ( $\mathrm{Li}$ et al. 2013a). This new material is synthesized by tannin and furfuryl alcohol, both inexpensive plant-derived chemicals. This $100 \%$ renewable bioresourced tannin/furanic thermosetting resin was found to have a glass transition temperature as high as $211^{\circ} \mathrm{C}$ and a $95 \%$ weight loss temperature of 244 and $240{ }^{\circ} \mathrm{C}$ in nitrogen and in air atmosphere, respectively. The char yield is as high as $52 \%$. Moreover, this new thermoset material shows excellent mechanical properties: Brinell hardness of $23 \mathrm{HBS}$, hence higher than commercial acrylic, polyvinyl chloride, and a little lower than solid polystyrene. The compressive breaking strength was found to be as high as 194.4 MPa, thus higher than filled phenolic resins, much higher than solid polystyrene and of acetal resins.

A first application of this material has been for the preparation of abrasive/grinding discs (Lagel et al. 2014b). This $100 \%$ biosourced, thermoset material based on condensed tannin-furanic thermoset resins, thus using biosourced raw materials, has been used as the resin matrix of solid abrasive wheels. Abrasive granules of different dimension and of different nature were used: inorganic materials such as aluminum trioxide and organic materials such as ground walnut shells. Moreover, this new thermoset material is produced by a simple process, easily transferrable into industry. The abrasive wheels based on this resin bonding of different mineral and organic abrasive powders were developed and characterized. They showed excellent abrasiveness properties when compared to commercial abrasive wheel (Lagel et al. 2014b).

Highly flexible films and strongly adhering surface finishes were prepared by reacting partially aminated polyflavonoid tannins with furfuryl alcohol in the presence of plasticizers such as glycerol or polyethyleneimine (Basso et al. 2014c) (Fig. 4). ${ }^{13} \mathrm{C}$ NMR analysis showed partial amination of the tannin under the conditions used and even the formation of some $-\mathrm{N}=$ bridges between flavonoids, although these were shown to be rare. MALDI-TOF analysis showed the presence of oligomers produced by the reaction of furfuryl alcohol with the flavonoids and the simultaneous self-condensation of furfuryl alcohol. Thus, linear methylene-furanic chains were also found to be linked to flavonoid reactive sites. Furthermore, side condensation reactions of furfuryl alcohol lead to the formation of methylene ether bridges between furanic nuclei, followed by rearrangement to methylene bridges with liberation of formaldehyde. This latter reacts with both the reactive sites of the flavonoid and of the furan rings to yield $-\mathrm{CH}_{2} \mathrm{OH}$ and $-\mathrm{CH}_{2}{ }^{+}$groups and methylene bridges.

Thermoplastic tannins obtained by total or partial acetylation, or other esterification, of flavonoid tannins were also obtained for specialized applications other than for wood (Nicollin et al. 2013b).

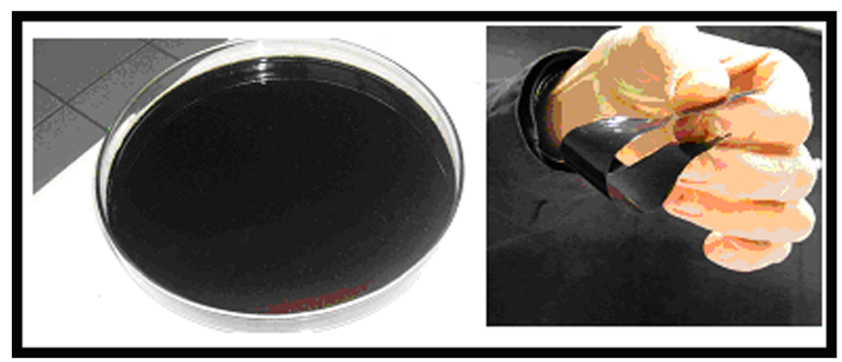

Fig. 4 Flexible tannin/furanic films and surface finishes 


\subsection{Biobased polyurethane resins}

Polyurethanes have become so ingrained in the daily life that their uses are so many that are difficult to enumerate. In relation to wood products, they are used as adhesives, for example in structural glulam and fingerjointing, as wood surfaces cover and paints and in wood products/ polyurethane foam sandwich panels. Polyurethanes are the product of the reaction of an isocyanate, generally a polymeric isocyanate, with a polyol. Due to this composition as regards green chemistry, the fundamental approach to obtained biosourced polyurethanes has been to substitute the synthetic polyol with natural polyols. The number of articles taking such an approach is so high, and the natural polyols tried are so numerous that the literature is full of it and still growing. Unfortunately, such an approach leads to polyurethanes only $50 \%$ biosourced as the other component used, the toxic isocyanate, is still necessary. It is not by repeating without end this type of approach for forever different natural polyols that polyurethanes biosourced to a much higher percentage are going to be obtained! The isocyanate is then the component to eliminate from these multifunction materials.
Routes to obtain polyurethanes without isocyanates exist, by using cyclic carbonate groups and diamines, but amazingly, these have been used with synthetic and not natural polyols (Rokicki and Piotrowska 2002; Nohra et al. 2013). Only recently, successful attempts to produce polyurethanes not only from natural polyols but also without any use of isocyanates have appeared in the literature (Thebault et al. 2014a, b). In the first of these works, hydrolysable chestnut tannins, which contain several hydroxyl groups, were reacted with dimethyl carbonate and then with hexamethylenediamine. The dried product was analyzed in MALDI-TOF, ${ }^{13} \mathrm{C}$ NMR, and Fourier transform infrared (FTIR) spectrometry. The spectra revealed the presence of urethane functions, and their yield was relatively high. This synthesis of polyurethanes is interesting because it does not depend on using isocyanates as reactants while instead utilizing a natural material, hydrolysable chestnut tannin, as their major constituent.

The reaction is in two steps, namely, first, a reaction of the phenolic moieties of the tannin with dimethyl carbonate or other dialkyl carbonate, linear or cyclic (propylene carbonate comes to mind).<smiles>C=CCOC(=O)OCCCOC(=O)Oc1cc(C(=O)OC)cc(OC(=O)OC)c1OC(=O)Oc1cc(C(=O)O)cc(OC(=O)OC)c1OC(=O)OC</smiles>

This is then followed by the second step. This being the reaction of this mix of compounds formed in the

previous reaction with a diamine, in this case with hexamethylenediamine,

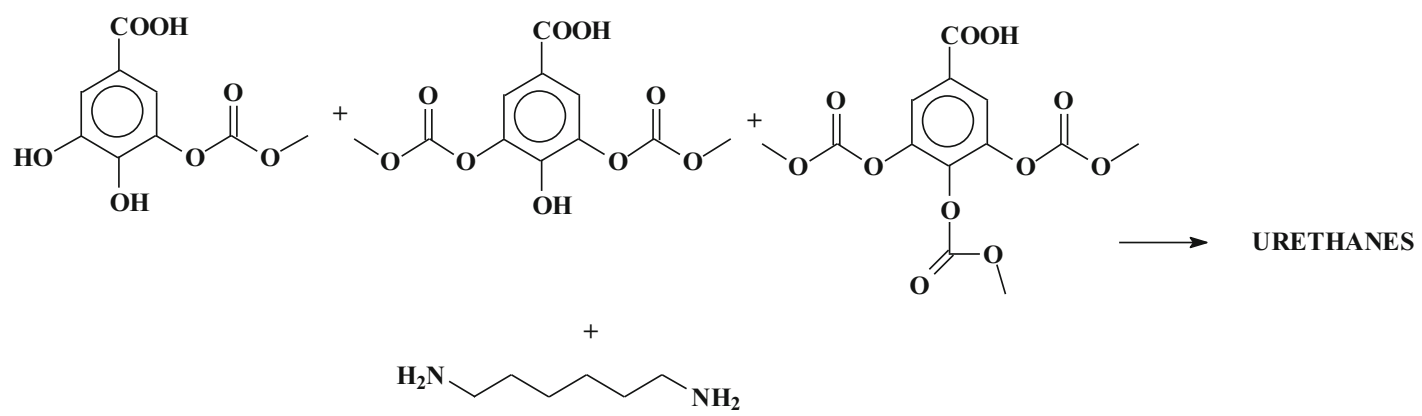


with a yield of approximately $50 \%$.

It is interesting that urethane linkages were also formed with some of the carbohydrates linked to the tannin polyphenols to form species such as

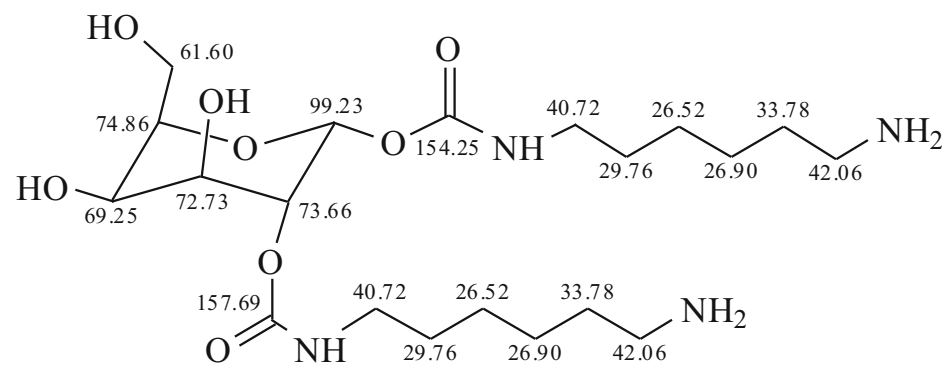

It is obvious that such an approach opens the route to the preparation of urethanes of very high level of biosourced origin, as both carbohydrates and polyphenols of different natures can be used.

The second of the works cited used the same approach but using a number of different condensed flavonoid tannins (Thebault et al. 2014b). Condensed flavonoid tannins from maritime pine (Pinus pinaster), mimosa (Acacia mearnsii), and radiata pine barks and quebracho (Schinopsis lorentzii and balansae) wood, thus both procyanidin types and other types, were first reacted with dimethyl carbonate. Then, hexamethylenediamine was added to these mixtures to form urethane linkages. The resulting materials were analyzed by FTIR spectroscopy, MALDI-TOF mass spectrometry, gel permeation chromatography (GPC), and thermogravimetric analysis (TGA). Finally, the resulting analysis indicated that the products obtained are polyurethanes. Even more interesting in the second work was the substitution of the hexamethylenediamine with a biosourced amine, namely condensed aminated tannins in which some of the hydroxyl groups of the tannin have been substituted by amino groups according to a reaction already reported (Braghiroli et al. 2013). In this manner well in excess of $80 \%$, almost $90 \%$ of the urethanes prepared were biosourced.

\subsection{Epoxy resins}

While epoxy resins are rarely used for wood due to their high price, nonetheless it is of interest that epoxy resins derived from wood and bark-derived natural materials have been developed (Nouailhas et al. 2011; Aouf et al. 2013) in competition with biobased epoxy resins obtained from vegetable oils (Stemmelen et al. 2011). Biobased epoxy resins were synthesized from a catechin molecule, one of the repetitive units in natural flavonoid biopolymers in condensed tannins and from both flavonoid and hydrolysable tannins themselves (Nouailhas et al. 2011). Their reactivity towards epichlorohydrin to form glycidyl ether derivatives was studied. The reaction products were characterized by both FTIR and NMR spectroscopy and chemical assay. The glycidyl ether of catechin (GEC) was successfully cured in various epoxy resin formulations. The GECs' thermal properties showed that these new synthesized epoxy resins displayed interesting properties compared to the commercial epoxy resins based on diglycidyl ether of bisphenol A (DGEBA). For instance, when incorporated up to $50 \%$ into the DGEBA resin, GEC did not modify the glass transition temperature. Epoxy resins formulated with GEC had slightly lower storage moduli but induced a decrease of the swelling percentage, suggesting that GEC-enhanced cross-linking in the epoxy resin networks.

\subsection{Wood welding}

The same mechanically induced friction welding techniques which are widely used in the plastic and car industries have recently been applied also to joining wood, without the use of any adhesive (Gfeller et al. 2003; Pizzi et al. 2004; Leban et al. 2004; Kanazawa et al. 2005; Ganne-Chedeville et al. 2005; Mansouri et al. 2009a, b; Omrani et al. 2009c). These work by melting some wood components and forming at the interface between the two wood surfaces to be joined a composite of entangled wood fibers drowned into a matrix of melted wood intercellular material, such as lignin and hemicelluloses. Linear mechanical friction vibration has been used to yield wood joints satisfying the relevant requirements for structural applications by welding at a very rapid rate (Gfeller et al. 2003; 
Leban et al. 2004; Mansouri et al. 2009a). Cross-linking chemical reactions also have shown to occur by CP-MAS ${ }^{13} \mathrm{C}$ NMR. These reactions, however, are lesser contributors during the very short welding period proper (Delmotte et al. 2008, 2009). They gain more, but still very limited, importance during the subsequent brief pressure holding period (Gfeller et al. 2003; Delmotte et al. 2008, 2009).

Also recently, high-speed rotation-induced wood dowel welding, without any adhesive, has been shown to rapidly yield wood joints of considerable strength (Kanazawa et al. 2005; Ganne-Chedeville et al. 2005). The mechanism of mechanically induced high-speed rotation wood welding is due to the temperature-induced softening and flowing of the intercellular material, mainly amorphous polymer material bonding the wood cells to each other in the structure of wood. This material is mainly composed of lignin and hemicelluloses. This flow of material induces high densification of the bonded interface. Wood species, relative diameter differences between the dowel and the receiving hole, and press time were shown to be parameters yielding significant strength differences. Other parameters were shown to have much lesser influence.

The relative diameter difference between dowel and substrate was the most important parameter determining joint strength performance (Kanazawa et al. 2005; GanneChedeville et al. 2005). The real determining parameter, however, is how fast the lignin/hemicelluloses melting temperature is reached. The greater the relative difference between the diameters of the dowel and of the substrate hole, the greater is the friction, hence more rapidly the lignin melting temperature is reached and a better welding is achieved.

The welding technology has been used to make furniture of different types (Segovia and Pizzi 2009; Segovia et al. 2010), to build structures both interior and exterior (Bocquet et al. 2006, 2007; O'Loising et al. 2012), and to obtain waterproof joints (Mansouri et al. 2011b; Omrani et al. 2009c; Pizzi et al. 2011; Pizzi et al. 2013b) as well as butt joints of very dense wood (Mansouri et al. 2010; Omrani et al. 2009a) of mechanical resistance comparable to that of glued finger joints.

It must be pointed out that waterproofing by the addition of rosin does also increase considerably the dry mechanical resistance of the joint, both linearly welded and dowel welded, yielding thus joints particularly strength competitive, a fact proven also by fracture mechanics on linearly welded joints.

This renders rather useless, uneconomical, and difficult to handle the purely mechanical approach to improve the dry strength of dowel joints promoted by other researchers (Girardon et al. 2013). The use of grooved surfaces already tried to no greater effect in linear welding (Omrani et al. 2009b) and especially the assumption (Girardon et al. 2013) incorrectly derived from adhesive application that using a dowel in a form of a screw, and thus increasing contact surface, will improve tensile strength of wood pieces held together by dowel welding is incorrect. Conversely, that the linear welded interface is weaker than solid wood has been proven by very advanced mechanical testing techniques (Gineste et al. 2012, 2013). Thus, linearly welded surfaces tend to be more stiff but weaker than glued surfaces: the use of environment-friendly adhesives would be advisable in such a case (see tannin-based cold sets or tannin-furanics, for example). Conversely, glued dowels and welded dowels present the same ultimate strength; thus, welding is very advisable as being faster. However, two wood surfaces held together by a number of welded dowels would produce a strong joint but not as strong as that obtained by gluing the whole interface with an environment-friendly adhesive. Lastly, welded dowels are strongly advisable to substitute both glued dowels as well as joints held together by steel nails (Bocquet et al. 2007).

\subsection{Biobased wood-derived foams}

Acid-catalyzed, rigid, totally fire-resistant bark tannin foams were first published in 1994 (Meikleham and Pizzi 1994). The main component was the tannin commercially extracted from the bark of mimosa trees. This first-generation foams have comparable physical and mechanical properties to synthetic phenolic rigid foams. They were based on the reaction of a mixture of mimosa tannin extract in some water and furfuryl alcohol (fortifying resin and heat generating), formaldehyde as a hardener, and diethyl ether as blowing agent. Para-toluene sulfonic acid was used as the acid catalyst. On its addition, the exothermal furfuryl alcohol self-condensation reaction started, inducing boiling and evaporation of the diethyl ether while simultaneously starting the hardening by cross-linking of the tannin-furfuryl alcohol-formaldehyde system. The formulation was optimized so that hardening occurred neither too early (hindering foaming otherwise) nor too late (leading to foam collapse). It was much later that the interest in biosourced materials has led to a considerable revival and research work in these foams with notable progress in this field.

At first, development concentrated mainly on exploring variations on the basic formulation of 1994 and intensive characterization of all the relevant physical, mechanical, thermal, and other properties (Pizzi et al. 2008; Tondi and Pizzi 2009; Tondi et al. 2008a, b, c, d; 2009a, b, c; 2010; Celzard et al. 2010, 2011) and of their carbonized counterparts (Tondi et al. 2008b, c; Tondi and Pizzi 2009). Afterwards, major advances were achieved first with tannin-furanic foams without formaldehyde (Basso et al. 2011) or modification with small amounts of polyisocyanate ( $\mathrm{Li}$ et al. 2012a), second with foams using a safer blowing agent, namely pentane, and even with no blowing agent at all (Basso et al. 2013a; Li et al. 2013b), third with foams using alternative non-toxic, nonvolatile aldehydes (Li et al. 2014a), and finally using the much more reactive and difficult to handle procyanidin-type tannins such as for example pine and spruce bark tannins (Cop et al. 2014; Lacoste et al. 2013, 2014). Even simplified foams in 
which the tannin was substituted with fine wood powder were tried (Srivastava and Pizzi 2014). All these types were rigid, acid-setting, fire-resistant foams. On top of very extensive characterization of these foams, even too numerous and extensive to be all mentioned here, very pointed studies on the kinetics of foaming and on its comparison with polyurethane foamings were completed (Basso et al. 2013b, c, d). Wood/foam sandwiches, where the wood could be plywood, solid wood, or a fiber composite, of excellent thermal and fire resistance and acoustic insulation were also developed (Zhou et al. 2013; Zhou and Pizzi 2013) (Fig 5).

A further step forward as regards wood application of these foams was achieved with the development of alkaline curing foams, thus capable of totally avoiding any potential damage to wood in contact with the acid residues of the foam catalyst (Basso et al. 2014a). Of big interest as a necessary counterbal- ance to polyurethane foams was to develop elastic tannin foams. For this, two different approaches were taken. The first consisted in including an external, non-volatile plasticizer to the rigid foam formulations so abundantly developed. This approach gave moderately elastic foams by the addition of glycerol (Li et al. 2012a, b). A second approach leading to highly flexible foams was to copolymerize up to $50 \%$ mimosa or quebracho tannin into polyurethane formulations by simultaneous synthesis (Basso et al. $2014 b$ ). These open cell foams were obtained by the simultaneous coreaction of condensed flavonoid tannins with an alxoxylated fatty amine and polymeric diphenylmethane isocyanate. The coreaction yielded highly flexible/elastic polyurethane foams. Copolymerized amine/isocyanate/tannin urethane oligomers such as for example<smiles>O=C(Nc1ccc(Cc2ccc(Cc3ccc(NC(=O)Oc4cc(O)cc5c4CC(O)C(c4cc(O)c(O)c(O)c4)O5)cc3)c([N+](=O)[O-])c2)cc1)Nc1ccc(OC(=O)Nc2ccc3c(c2)OC(c2cc(O)c(O)c(O)c2)C(O)C3)cc1</smiles>
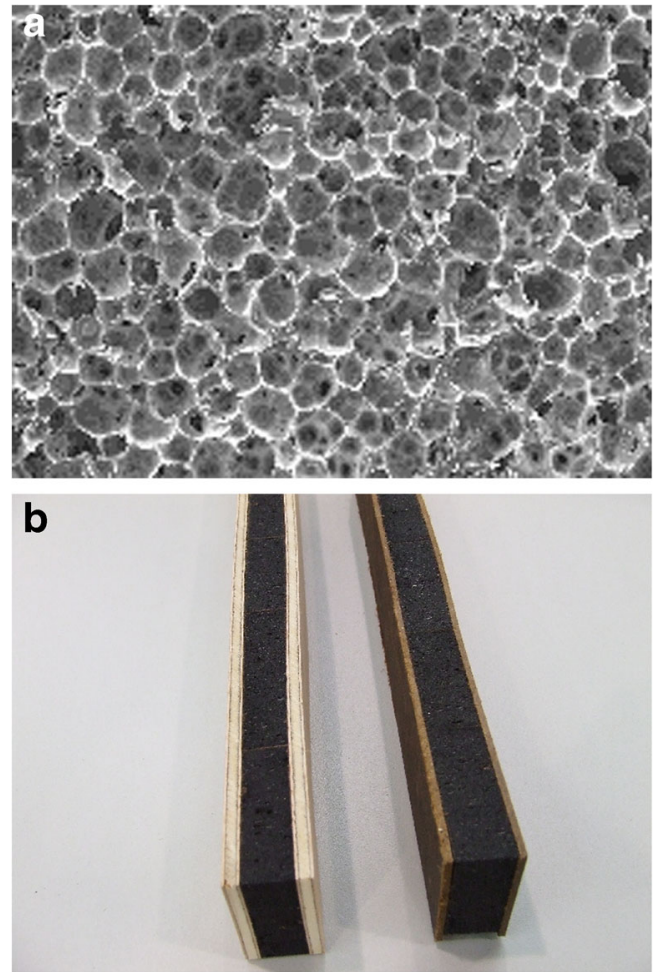

Fig 5 Tannin-furanic rigid foams. Scanning electron microscope view of the cellular structure and an example of application to mixed wood/foam sandwich panels for sound and fire insulation were identified by ${ }^{13} \mathrm{C}$ NMR and MALDI-TOF spectroscopy (Basso et al. 2014b, d).

In general, between 30 and $50 \%$ of natural tannins is added to the components used to obtain polymerization of the polyurethane. The characteristic of these new, partially biosourced polyurethanes is that the tannin present slows down burning, some of them are even flame self-extinguishing and if burning they neither flow nor asperge flaming material around, contrary to what occurs with normal polyurethanes. This limits the possibility of transmitting fire to other materials in the same environment. Cyclic compression tests were carried out showing that after 50 cycles, foam recovery was in excess of $80 \%$. The coreactions that occurred were as in Fig. 6. It is interesting to note that complex but highly effective polyurethane-phenolic systems were obtained by coreaction of only $30 \%$ isocyanate with a coreaction mix of tannin, glyoxal, and furfuryl alcohol. This was based on the wellknown high reactivity of the $-\mathrm{NCO}$ isocyanate group with aromatic benzyl alcohol $\left(\mathrm{Ar}-\mathrm{CH}_{2} \mathrm{OH}\right)$ groups already used in wood adhesives (Pizzi and Walton 1992; Pizzi et al. 1993,1994). In absence of water, it showed to be a much more effective method than any of the other exposed above, with the tannin foam being again fire-resistant (Basso et al. 2014b,d). 


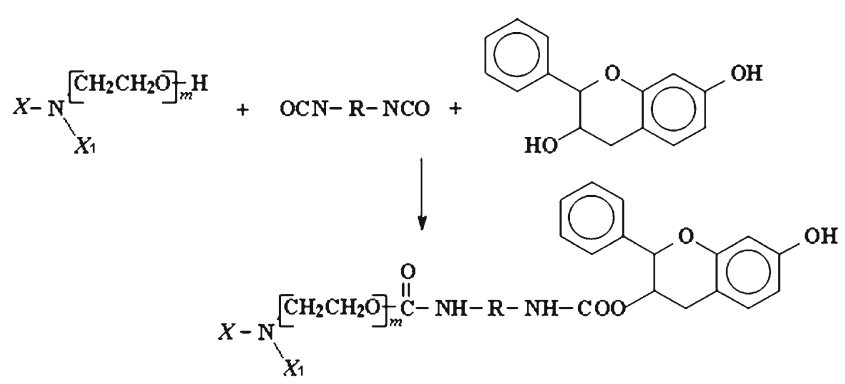

Fig. 6 Coreactions of isocyanate, amine, and flavonoid tannins to yield mixed elastic, flexible polyurethanes

Some unusual applications such as using the first- and second-generation foams as filters for the elimination of heavy metals such as $\mathrm{Pb}$ and $\mathrm{Cu}$ in water were also investigated (Oo et al. 2009; Tondi et al. 2009b). These were based on the welldocumented ability of the B-ring of flavonoids to form orthodiphenol complexes with heavy metals.

\subsection{Biobased wood preservatives}

The search for biobased, environment-friendly, non-toxic green wood preservatives has been on for a long time, this being due to the acute need and interest in diminishing or even better eliminating the toxicity of existing preservation systems.

At present, in Europe, only impregnation of wood with a furanic resin that is then cured in situ is accepted and codified as an environment-friendly non-toxic preservative. Furanic resins from furfural and furfuryl alcohol are biosourced products, and once in their cured resin form, they are indeed nontoxic and non-leaching. What detract from such system however are a few points: the system is relatively expensive as to achieve the wanted effect a rather high percentage of resin on wood is necessary. Second, furanic monomers before being hardened in an insoluble resin are slightly toxic, this not being a major problem. Third, a furanic resin is incredibly resistant to both fire and water, that means once out of service, the elimination of the treated wood may well constitute a problem. This said is anyhow excellent that the era of commercial green preservatives has at least started. There are several other published possibilities in this field that merit to be presented and kept in mind.

The first class of wood preservatives described here was found by chance. Copper soaps with carboxylic acid groups of unsaturated fatty acids such those of edible vegetable oils which are non-toxic, such as maize oil, sunflower oil, and other as well as with resin acids of rosin, were shown to have effectiveness and long-term durability as ground contact wood preservatives (Pizzi 1993a). Twenty-five-year-long field tests against termites and fungal attack have shown their long-term effectiveness (Pizzi 1993b). Their mechanism of action is based on their fixation by three radical reactions to the wood constituent matrix (Pizzi 1993a,b), namely by (i) self-polymerization, (ii) coreaction with carbon-carbon double bonds of lignin, and (iii) coreaction with lignin aromatic nuclei. Fixation can be obtained at ambient temperature but can be considerably accelerated by moderate heat application or by the use at ambient temperature of radical initiator couples (redox or other) as well as by the ultraviolet radiation of daylight. $\mathrm{Cu}^{2+}$ is the biocide species used, although the system can be used with other positively charged biocides. $\mathrm{Cu}^{2+}$ is attached to the preservative network formed throughout the wood by the radical cross-linking, on the - $\mathrm{COOH}$ groups on the organic part of the preservative. Its binding is much stronger than for coordination type bonds, hence its long durability. The biocidal mechanism is based on the release of $\mathrm{Cu}^{2+}$ by hydrolysis of the $-\left(\mathrm{COO}^{-}\right)_{2} \mathrm{Cu}^{2+}$ bonds under humid to very humid conditions and on the reforming of the same bond on redrying of the treated timber in service. The water-repellent effect imparted by the cross-linked network contributes to minimize water ingress and thus to durability. Such a wood preservation system can then be summarized as a mode of increasing long-term biocidal performance in treated timber by allowing the biocide to be free when needed while remaining fixed when not needed. These preservatives are easy to manufacture but are organic solvent-based wood preservatives, the organic solvent being evaporated or recovered once the wood has been treated.

Their preparation and fixation into the wood are shown schematically in Fig. 7.

The same is obtainable with the copper soaps of resinites, oligomeric terpenic acids of rosin issued as by-product from the pulp and paper industry (Pizzi 1993a, b) (Fig. 8).
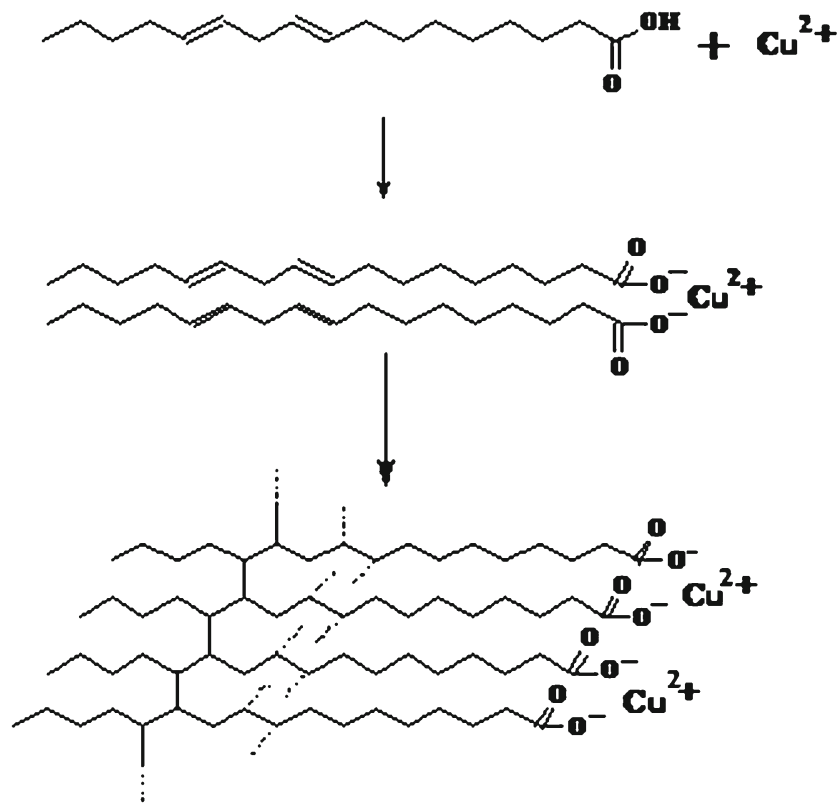

Fig. 7 Schematic representation of the copper/unsaturated oils wood preservative preparation followed by in situ networking in the wood itself 
Fig. 8 Schematic representation of the copper/resinite wood preservative preparation followed by in situ networking in the wood itself

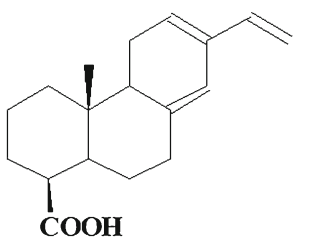

As copper is still a heavy metal and water-carried wood preservatives are preferable to solvent carried preservatives, a different approach was taken. Boric acid is when used to a limited extent, a more acceptable and environment-friendly wood preservative. The question is that being the boric acid anion negatively charged, what polymer can be used to fix it to the wood. Unsaturated fatty acids, being acid too, are thus unsuitable. The most abundant natural polymers carrying basic groups are proteins, thus amine and especially amidic groups. This approach led them to protein borates and polyborate wood preservatives.

Wood preservatives based on protein borates, both obtained by just mixed water solutions of protein and boric acid, as well as in the case of premanufactured protein borate salts were shown to be a good method of greatly retarding the leaching of boron from treated timber (Thevenon et al. 1997, 1998a, b, c; Thevenon and Pizzi 2003). Thus, just premixed albumin + boric acid, premanufactured protein borate, and soy protein + boric acid all showed good preservative performance and much retarded leaching of boron.

\section{some $\mathrm{R}$ carry amine groups $\left(-\mathrm{NH}_{2}\right)$}<smiles>[R]C(NC)C(=O)NC([R])C(=O)NCC</smiles>

\section{Peptide bonds $=$ amide groups PROTEINS}

All the $-\mathrm{NH}_{2}$ amine groups and the $-\mathrm{NH}$ - amide groups of the protein can react with boric acid to form protein borates.

Accelerated biological tests indicated that boric acid partially fixed to timber by formation of a salt with the protein which is then insolubilized in situ by heat-induced coagulation
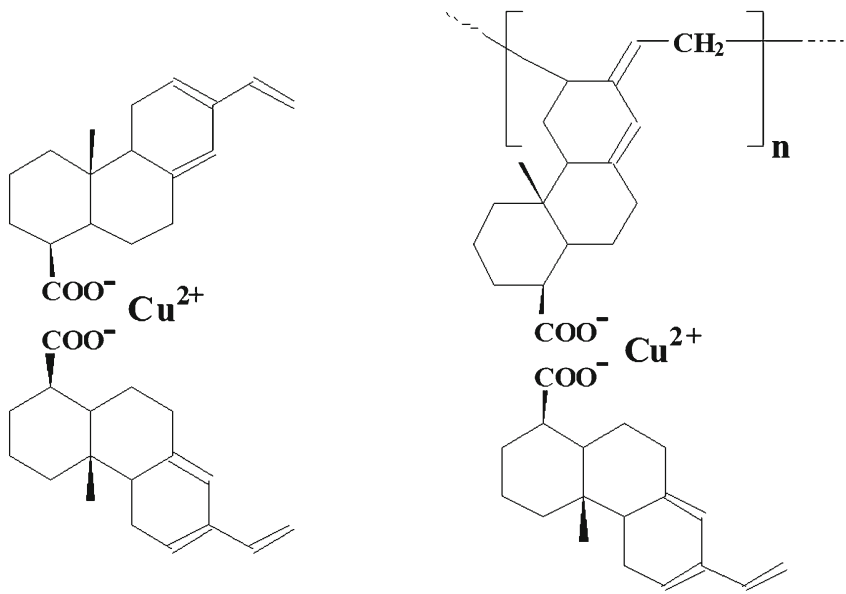

can yield durability performances comparable to those obtained with CCA wood preservatives. The tests showed that such wood preservatives can be classified as long-term, wide-spectrum, ground contact, heavy duty, environment-friendly green wood preservatives (Fig. 9). The mechanism is one of partially reversible rather than totally irreversible fixation of boron, leaving at all time small amounts of boron free to exercise its antifungal activity but drastically diminishing its tendency to leach and greatly retarding its leaching. The timber undergoes just a single step waterborne vacuum/pressure treatment as for traditional wood preservatives.

The easy synthesis of another chemical compound, ammonium borate oleate (Lyon et al. 2007a), combining water repellence of oleic acid and biocidal effect of boric acid, the
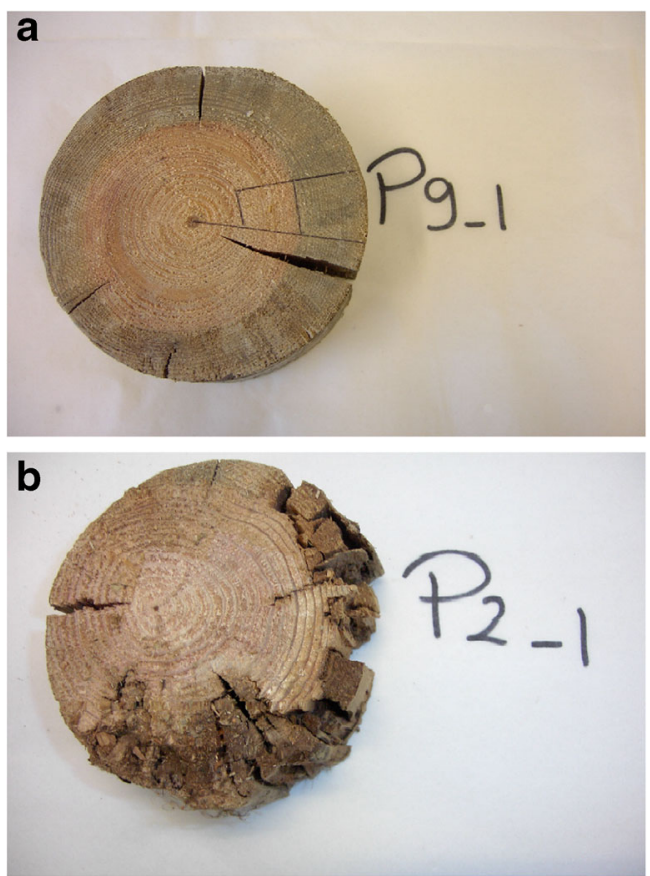

Fig. 9 Example of slices of field test pole samples treated with protein borates (left) and an untreated control (right) after 2 years field exposure 
two linked by ammonia, marks a further step in the search of green preservatives (Fig. 10).

Again, after wood impregnation, a fixed network is induced in the wood by radical polymerization of the oleic acid through its $\mathrm{C}=\mathrm{C}$ double bonds, to render the system even more water-repellent and conserve the boric acid for a longer time within the wood. Formulations including 4 mol of oleic acid for one of boric acid and one of ammonia have shown the best performance with about $52 \%$ boron remaining after weathering. Toxicity threshold around $2.0 \mathrm{~kg} / \mathrm{m}^{3}$ of timber impregnated with low amounts of this wood preservative towards termites of the Coptotermes formosanus species showed the positive effect of combining the water-repellent effect of oleic acid and the biocidal capacity of boric acid. The treatment of wood with this salt is carried out at ambient temperature and so is the radical polymerization of the oleic acid part.

The preparation of this mixed salt was undertaken to further improve the interaction of oil and boric acid and boric acid fixation. Thus, on a precedent work, it had been found that a thermal treatment of wood with vegetable oils provides boron retention of about $30 \%$ of initial amount depending on oil-drying properties (Lyon et al. 2007b). Linseed oil was found to be the most effective, followed by soybean oil and rapeseed oil. Durability of wood specimens has been enhanced by application of linseed oil alone, but this definitely is not enough to reduce termite's attack of C. formosanus. Treating wood with a $1.0 \% \mathrm{w} / \mathrm{w}$ boric acid solution prior to oil treatment instead protected wood from both termite and fungal degradations. Effectiveness against termites is mainly due to boron retention, but the hydrophobic oil also forms a barrier decreasing fungal penetration. A boron effectiveness threshold around $0.7 \mathrm{~kg} / \mathrm{m}^{3}$ was recorded, lower than classical boron treatment thresholds indicating that oil-water repellence reinforces the boron biostatic effect.

Other approaches to partially fix boric acid as a low toxicity wood preservative to decrease markedly its leachability were also taken. Preservative systems based on the cross-linking and hardening of condensed tannins by hexamethylenetetramine (hexamine) (see paragraph on tannin-hexamine adhesives in this review), where boric acid is complexed onto the network by the ortho-diphenolic hydroxyl groups of the Bring of flavonoids, have also been developed (Thevenon et al. 2009, 2011; Tondi et al. 2012a, b). This approach had already been tried but just without polymerizing and networking the tannin by the mean of hexamine, with improved and lengthened but still shorter term durability (Pizzi and Baecker 1996)

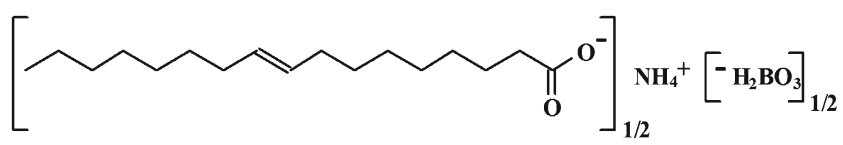

Fig. 10 Schematic formula of ammonium borate oleate wood preservative than the later system. The introduction of the hexamine and the cross-linking of the system through its reaction with the tannin made the difference to greatly extend the preservative durability. These too were found to markedly slow down the leaching of boron. They significantly enhanced wood durability before and after leaching once tested against basidiomycetes according to standard guidelines. Coupling immersion of the wood so treated in hot unsaturated vegetable oil yielded equally good results but indicated that for this system, the hot oil treatment is not necessary (Thevenon et al. 2009).

\section{Conclusions}

The above review is only a representative sample of the ferment of ideas and explosion in research interest and work in green materials, and this is just on products limited to wood and for or from wood. On each subject presented, there are more original articles, the writer only having limited himself to report the more topical and interesting ones to give the reader a view of what is possible and has already been achieved in this field. By necessity, this view is still unavoidably partial, seen the vastness of the field treated. It is only hoped that such synthetic review will show that this is not only a field bound to greatly expand in the future but also that many more applications, products, and ideas are most likely to arise in the future.

Funding The numerous findings presented in this review article have been in part funded by the ANR-Agence Nationale de la Recherche (France), LABEX Arbre, European Commission, The Silva-Indunor company.

Open Access This article is distributed under the terms of the Creative Commons Attribution License which permits any use, distribution, and reproduction in any medium, provided the original author(s) and the source are credited.

\section{References}

Abdullah UH, Pizzi A, Rode K, Delmotte L, Mansouri HR (2013a) Mimosa tannin resins for impregnated paper overlays. Eur J Wood Prod 71:153-162

Abdullah UH, Zhou X, Pizzi A, Merlin A (2013b) Surface quality of plywood overlaid with mimosa (Acacia mearnsii) tannin and melamine urea formaldehyde impregnated paper: effects of moisture content of resin-impregnated papers before pressing on the physical properties of overlaid panels. Int Wood Prod J 4:253-256

Alma MH, Yoshioka M, Yao Y, Shiraishi N (1996) The preparation and flow properties of $\mathrm{HCl}$ catalyzed phenolated wood and its blends with commercial novolak resins. Holzforschung 50:85-90

Alma MH, Yoshioka M, Yao Y, Shiraishi N (1998) Preparation of sulphuric acid-catalyzed phenolated wood resin. Wood Sci Technol 32:397-308 
Amaral-Labat GA, Pizzi A, Goncalves AR, Celzard A, Rigolet S (2008) Environment-friendly soy flour-based resins without formaldehyde. J Appl Polym Sci 108:624-632

AoufC, Nouailhas H, Fache M, Calliol S, Boutevin B, Fulcrand H (2013) Multi-functionalisation of gallic acid. Synthesis of a novel bio-based epoxy resin. Eur Polym J 49:1185-1195

Bailey PS (1978) Ozonation in organic chemistry. Academic, New York

Ballerini A, Despres A, Pizzi A (2005) Non-toxic, zero-emission tanninglyoxal adhesives for wood panels. Holz Roh Werkst 63:477-478

Basso MC, Li X, Giovando S, Fierro V, Pizzi A, Celzard A (2011) Green, formaldehyde-free, foams for thermal insulation. Adv Mat Lett 2: 378-382

Basso MC, Giovando S, Pizzi A, Celzard A, Fierro V (2013a) Tannin/ furanic foams without blowing agents and formaldehyde. Ind Crop Prod 49:17-22

Basso MC, Pizzi A, Celzard A (2013b) Influence of formulation on the dynamics of preparation of tannin based foams. Ind Crop Prod 51: 396-400

Basso MC, Pizzi A, Celzard A (2013c) Dynamic monitoring of tannin foams preparation: surfactant effects. Bioresources 8:5807-5816

Basso MC, Pizzi A, Celzard A (2013d) Dynamic foaming behaviour of polyurethane vs. tannin/furanic foams. J Renew Mat 1:273-274

Basso MC, Giovando S, Pizzi A, Lagel MC, Celzard A (2014a) Alkaline tannin rigid foams. J Renew Mat 2:182-185

Basso MC, Giovando S, Pizzi A, Pasch H, Pretorius N, Delmotte L, Celzard A (2014b) Flexible-elastic copolymerized polyurethanetannin foams. J Appl Polym Sci 131(13): doi: 10.1002/app.40499

Basso MC, Lacoste C, Pizzi A, Fredon E, Delmotte L (2014c) Flexible tannin-furanic films and lacquers. Ind Crop Prod 61:352-360

Basso MC, Pizzi A, Lacoste C, Delmotte L, Al-Marzouki FA, Abdalla S, Celzard A (2014d) Tannin-furanic-polyurethane foams for industrial continuous plant lines. Polymers in press

Belgacem MN, Gandini A (2003) Furan-based adhesives. In: Pizzi A, Mittal KL (eds) Handbook of adhesive technology, 2nd edn. Marcel Dekker, New York, pp 615-634

Blanchet P, Cloutier A, Riedl B (2000) Particleboard made from hammer milled black spruce bark residues. Wood Sci Technol 34:11-19

Bocquet JF, Pizzi A, Resch L (2006) Full-scale (industrial) wood floor using welded through dowels. J Adhes Sci Technol 20:1727-1739

Bocquet JF, Pizzi A, Despres A, Mansouri HR, Resch L, Michel D, Letort F (2007) Wood joints and laminated wood beams assembled by mechanically welded wood dowels. J Adhes Sci Technol 21:301317

Braghiroli F, Fierro V, Celzard A, Pizzi A, Rode K, Radke W, Delmotte L, Parmentier J (2013) Condensation reaction of flavonoid tannins with ammonia. Ind Crop Prod 44:330-335

Calvé LR (1999) Fast cure and pre-cure resistant cross-linked phenolformaldehyde adhesives and methods of making same. Can. Pat. 2042476

Celzard A, Zhao W, Pizzi A, Fierro V (2010) Mechanical properties of tannin-based rigid foams undergoing compression. Mater Sci Eng A527:4438-4446

Celzard A, Fierro V, Amaral-Labat G, Pizzi A, Torero J (2011) Flammability assessment of tannin-based cellular materials. Polym Degrad Stab 96:477-482

Chen CM (1996) State of the art report: adhesives from renewable resources. Holzforschung Holzverwertung 48:58-60

Conner AH, River BH, Lorenz LF (1986) Carbohydrate modified phenolformaldehyde resins. J Wood Chem Technol 6:591-596

Conner AH, Lorenz LF, River BH (1989) Carbohydrate-modified PF resins formulated at neutral conditions. Adhes Renew Resour ACS Symp Ser 385:355-369

Cop M, Laborie M-P, Pizzi A, Sernek M (2014) Curing characterisation of spruce tannin-based foams using the advances isoconversional method. Bioresources 9:4643-4655
Cornillet C, Labat G, Gaillard JM (2012) Analyse de cycles de vie, FCBA, project BEMA, bois eco materiaux aquitaine, rapport de restitution, pp. 81-84

Delmotte L, Ganne-Chedeville C, Leban J-M, Pizzi A, Pichelin F (2008) CP-MAS ${ }^{13} \mathrm{C}$ NMR and FTIR investigation of the degradation reactions of polymer constituents in wood welding. Polym Degrad Stab 93:406-412

Delmotte L, Mansouri HR, Omrani P, Pizzi A (2009) Influence of wood welding frequency on wood constituents. Chemical modifications. J Adhes Sci Technol 23:1271-1279

Deng S, Du G, Li X, Pizzi A (2014a) Performance and reaction mechanism of zero formaldehyde-emission urea-glyoxal (UG) resin. J Taiwan Inst Chem Eng 45:2029-2038

Deng S, Pizzi A, Du G, Zhang J, Zhang J (2014b) Synthesis and chemical structure of a novel glyoxal-urea-formaldehyde (GUF) cocondensed resins with different MMU/G molar ratios by ${ }^{13} \mathrm{CNMR}$ and MALDI-TOF-MS. J Appl Polym Sci. doi:10.1002/app.41009

El Mansouri N-E, Pizzi A, Salvado' J (2007a) Lignin-based polycondensation resins for wood adhesives. J Appl Polym Sci 103:1690-1699

El Mansouri N-E, Pizzi A, Salvado' J (2007b) Lignin-based wood panel adhesives without formaldehyde. Holz Roh Werkst 65:65-70

Felby C, Pedersen LS, Nielsen BR (1997) Enhanced auto adhesion of wood fibers using phenol oxidases. Holzforschung 51:281-286

Fung DPC, Shen KC, Calvé L (1977) Spent sulphite liquor-sulphuric acid binder: its preparation and some chemical properties. Report OPX 180 E, Eastern Forest Products Laboratory, Ottawa

Ganne-Chedeville C, Pizzi A, Thomas A, Leban J-M, Bocquet J-F, Despres A, Mansouri HR (2005) Parameter interactions in twoblock welding and the wood nail concept in wood dowel welding. J Adhes Sci Technol 19:1157-1174

Garcia R, Pizzi A (1998a) Polycondensation and autocondensation networks in polyflavonoid tannins, part 1: final networks. J Appl Polym Sci 70:1083-1091

Garcia R, Pizzi A (1998b) Polycondensation and autocondensation networks in polyflavonoid tannins, part 2: polycondensation vs autocondensation. J Appl Polym Sci 70:1093-1110

Gardner D, Sellers T Jr (1986) Formulation of a lignin-based plywood. For Prod J 36:61-67

Gfeller B, Zanetti M, Properzi M, Pizzi A, Pichelin F, Lehmann M, Delmotte L (2003) Wood bonding by vibrational welding. J Adhes Sci Techn 17:1425-1590

Gineste B, Cognard JY, Pizzi A (2012) Analysis of the mechanical behaviour of wood and welded wood under tensile-shear loads using a modified Arcan device. J Adhes Sci Techn 26:1717-1731

Gineste B, Diakhate M, Cognard JY, Pizzi A (2013) Analyse du comportement mecanique de bois et d'assemblages de bois soudes par friction sous sollicitations de traction-cisaillement en utilisant un montage Arcan modifie, Comptes Rendus 18 JNC, Ecole Centrale de Nantes, Nantes, France, June

Girardon S, Bocquet JF, Triboulot P (2013) Amelioration des performances mecaniques des assemblages bois sur bois chevilles par preparation des interfaces: application a la realisation d'elements de structure, 21st Congres Francais de Mecanique, Bordeaux, August, pp. 1-6

Hettiarachy NS, Kalapotly U, Myers DJ (1995) Alkali-modified soy protein with improved adhesive and hydrophobic properties. J Am Oil Chem Soc 72:1461-1464

Jang Y, Li K (2013) Adhesion mechanisms of an adhesive that is solely based on natural materials. Wood Adhesives 2013, Forest Prod Soc, Toronto, Canada, October

Kamoun C, Pizzi A (2000) Mechanism of hexamine as a nonaldehyde polycondensation hardener. Holzforschung Holzverwertung 52:16-19

Kamoun C, Pizzi A, Zanetti M (2003) Upgrading of MUF resins by buffering additives - part 1: hexamine sulphate effect and its limits. J Appl Polym Sci 90:203-214 
Kanazawa F, Pizzi A, Properzi M, Delmotte L, Pichelin F (2005) Influence parameters in wood dowels welding by high speed rotation. J Adhes Sci Technol 19:1025-1038

Kharazipour A, Haars A, Shekholeslami M, Hüttermann A (1991) Enzymgebundene holzwerkstoffe auf der basis von lignin und phenoloxidasen. Adhäsion 35:30-36

Kharazipour A, Mai C, Hüttermann A (1998) Polyphenols for compounded materials. Polym Degrad Stab 59:237-243

Kim S, Kim H-J (2003) Curing behaviour and viscoelastic properties of pine and wattle tannin based adhesives studied by dynamic mechanical thermal analysis and FT-IR-ATR spectroscopy. J Adhes Sci Technol 17:1369-1384

Lacoste C, Basso MC, Pizzi A, Laborie M-P, Celzard A, Fierro V (2013) Pine tannin-based rigid foams: mechanical and thermal properties. Ind Crop Prod 43:245-250

Lacoste C, Pizzi A, Basso MC, Laborie M-P, Celzard A (2014) Pinus pinaster tannin/furanic foams: part 1, formulation. Ind Crop Prod 52: 450-456

Lagel MC, Pizzi A, Basso MC (2014b) Development and characterisation of abrasive wheels with a tannin-furanic resin matrix. Industrial crops prod submitted

Lagel MC, Pizzi A, Redl A (2014b) Phenol-wheat protein-formaldehyde adhesives for wood-based panels. Pro Ligno 10:3-17

Lagel MC, Pizzi A, Redl A (2014c), Colles à bois pour la préparation de panneaux de particules, PCT/IB2014/065129

Leban J-M, Pizzi A, Wieland S, Zanetti M, Properzi M, Pichelin F (2004) $\mathrm{X}$-ray microdensitometry analysis of vibration-welded wood. J Adhes Sci Technol 18:673-685

Lei H, Pizzi A, Navarrete P, Rigolet S, Redl A, Wagner A (2010) Gluten protein adhesives for wood panels. J Adhes Sci Technol 24:15831596

Li X, Basso MC, Fierro V, Pizzi A, Celzard A (2012a) Chemical modification of tannin/furanic rigid foams by isocyanates and polyurethanes. Maderas Ci Technol 14:257-265

Li X, Pizzi A, Cangemi M, Fierro V, Celzard A (2012b) Flexible natural tannin-based and protein-based biosourced foams. Indus Crop Prod 37:389-393

Li X, Lacoste C, Pizzi A, Fierro V, Celzard A (2013a) Physical properties of tannin/furanic resin foamed by different blowing agents. Bioresources 8:743-752

Li X, Nicollin A, Pizzi A, Zhou X, Sauget A, Delmotte L (2013b) Natural tannin/furanic thermosetting moulding plastics. RSC (R Chem Soc) Adv 3:17732-17740

Li X, Pizzi A, Zhou X, Celzard A, Fierro V (2014a) Formaldehyde-free prorobitenidin/profisetinidin tannin/furanic foams based on alternative aldehydes: glyoxal and glutaraldehyde. J Renew Mat in press

Liu Y, Li K (2002) Chemical modification of soy protein for wood adhesives. Macromol Rapid Commun 23:739-742

Liu Y, Li K (2007) Development and characterization of adhesives from soy protein for bonding wood. Int J Adhes Adhes 27:59-64

Lopez-Suevos F, Riedl B (2003) Effects of Pinus pinaster bark extracts content on the cure properties of tannin-modified adhesives and on bonding of exterior grade MDF. J Adhes Sci Technol 17:1507-1522

Lorenz L, Frihart CR, Wescott JM (2006) Analysis of soy flour/phenolformaldehyde adhesives for bonding wood. Proceedings Wood Adhesives 2005, Forest Products Society, Madison, Wisconsin

Lyon F, Pizzi A, Imamura Y, Thevenon M-F, Nami Kartal S, Gril J (2007a) Leachability and termite resistance of wood treated with a new preservative: ammonium borate oleate. Holz Roh Werkst 65: 359-366

Lyon F, Thevenon M-F, Hwang W-J, Imamura Y, Gril J, Pizzi A (2007b) Effect of an oil heat treatment on leachability and biological resistance of boric acid impregnated wood. Ann For Sci 64:673-678

Mansouri HR, Omrani P, Pizzi A (2009a) Improving the water resistance of linear vibration-welded wood joints. J Adhes Sci Technol 23:63-70
Mansouri HR, Pizzi A, Fredon E (2009b) Honeymoon fast set adhesives for glulam/fingerjoints of higher natural materials content. Eur J Wood Prod 67:207-210

Mansouri HR, Leban J-M, Pizzi A (2010) End-grain butt joints obtained by friction welding of high density eucalyptus wood. Wood Sci Technol 44:399-406

Mansouri HR, Navarrete P, Pizzi A, Tapin-Lingua S, Benjelloun-Mlayah B, Rigolet S (2011a) Synthetic-resin-free wood panel adhesives from low molecular mass lignin and tannin. Eur J Wood Prod 69: 221-229

Mansouri HR, Pizzi A, Leban J-M, Delmotte L, Lindgren O, Vaziri M (2011b) Causes of the characteristic improved water resistance in pine wood linear welding. J Adhes Sci Technol 25:1987-1995

Meikleham N, Pizzi A (1994) Acid and alkali-setting tannin-based rigid foams. J Appl Polym Sci 53:1547-1556

Meikleham N, Pizzi A, Stephanou A (1994) Induced accelerated autocondensation of polyflavonoid tannins for phenolic polycondensates, part $1:{ }^{13} \mathrm{C} \mathrm{NMR},{ }^{29} \mathrm{Si} \mathrm{NMR}, \mathrm{X}$-ray and polarimetry studies and mechanism. J Appl Polym Sci 54:1827-1845

Miller RB, Shonfeld U (2002) Company Literature, Preform Raumgliederungssysteme GmBH, Esbacher Weg 15, D-91555 Feuchtwangen, Germany

Navarrete P, Pizzi A, Tapin-Lingua S, Benjelloun-Mlayah B, Pasch H, Rode K, Delmotte L, Rigolet S (2012) Low formaldehyde emitting biobased wood adhesives manufactured from mixtures of tannin and glyoxalated lignin. J Adhes Sci Technol 26:1667-1684

Newman WH, Glasser WG (1985) Engineering plastics from lignin, XII: synthesis and performance of lignin adhesives with isocyanate and melamine. Holzforschung 39:345-353

Nicollin A, Li X, Girods P, Pizzi A, Rogaume Y (2013a) Fast pressing composite using tannin-furfuryl alcohol resin and vegetal fibers reinforcement. J Renew Mat 1:311-316

Nicollin A, Zhou X, Pizzi A, Gigsby WJ, Rode K, Delmotte L (2013b) MALDI-TOF and 13C NMR analysis of a renewable resource additive - thermoplastic acetylated tannins. Ind Crop Prod 49:851857

Nimz HH (1983) Lignin-based adhesives. In: Pizzi A (ed) Wood adhesives chemistry and technology, vol 1. Marcel Dekker, New York, pp 247-288

Nimz HH, Hitze G (1980) The application of spent sulfite liquor as an adhesive for particleboards. Cell Chem Technol 14:371-382

Nohra B, Candy L, Blanco J-F, Guerin C, Raoul Y, Mouloungui Z (2013) From petrochemical polyurethanes to biobased polyhydroxyurethanes. Macromolecules 46:3771-3792

Nouailhas H, Aouf C, Le Guerneve C, Caillol S, Boutevin B, Fulcrand H (2011) Synthesis and properties of biobased epoxy resins. Part 1. Glycidylation of flavonoids by epichlorohydrin. J Polym Sci Part A 49:2261-2270

Novotny EE, Johnson WW (1931) Furfural-urea resin and process of making the same. U.S. Patent $1,827,824$

O'Loising C, Oudjene M, Shotton E, Pizzi A, Fanning P (2012) Mechanical behaviour and 3D stress analysis of multilayered wooden beams made with welded-through wood dowels. Compos Struct 94:313-312

Omrani P, Mansouri HR, Pizzi A (2009a) Wood end grain linear welding: influence of wood grain direction on linear welding. J Adhes Sci Technol 23:2047-2055

Omrani P, Mansouri HR, Pizzi A (2009b) Linear welding of grooved wood surfaces. Holz Roh Werkst 67:479-481

Omrani P, Pizzi A, Mansouri H, Leban J-M, Delmotte L (2009c) Physicochemical causes of the extent of water resistance of linearly welded wood joints. J Adhes Sci Technol 23:827-837

Oo CW, Kassim MJ, Pizzi A (2009) Characterization and performance of Rhizophora apiculata mangrove polyflavonoid tannins in the adsorption of copper (II) and lead (II). Ind Crop Prod 30:152-161 
Petersen H (1968) Process for the production of formaldehyde-free finishing agents for cellulosic textiles and the use of such agents. Textilveredlung 2:51-62

Pichelin F (1999b) Manufacture of oriented strandboard with high moisture tolerant adhesives. PhD thesis, University of Hamburg, Hamburg, Germany

Pichelin F, Kamoun C, Pizzi A (1999) Hexamine hardener behavioureffects on wood glueing, tannin and other wood adhesives. Holz Roh Werkst 57:305-317

Pichelin F, Nakatani M, Pizzi A, Wieland S, Despres A, Rigolet S (2006) Thick wood panels bonded industrially with formaldehyde free tannin adhesives. For Prod J 56:31-36

Pizzi A (1978) Chemistry and technology of cold- and thermosetting tannin-based exterior wood adhesives. Ph.D thesis, University of the Orange Free State, Bloemfontein, South Africa

Pizzi A (1993a) A new approach to non-toxic, wide-spectrum, groundcontact wood preservatives, part 1: approach and reaction mechanisms. Holzforschung 47:253-260

Pizzi A (1993b) A new approach to non-toxic, wide-spectrum, groundcontact wood preservatives, part 2: accelerated and field biological tests. Holzforschung 47:343-348

Pizzi A (1994a) Hardening mechanism of tannin adhesives with hexamine. Holz Roh Werkst 52:229

Pizzi A (1994b) Advanced wood adhesives technology. Marcel Dekker, New York

Pizzi A, Baecker AW (1996) A new boron fixation mechanism for nontoxic wood preservatives. Holzforschung 50:507-510

Pizzi A, Meikleham N (1995) Induced accelerated autocondensation of polyflavonoid tannins for phenolic polycondensates - part III: CPMAS ${ }^{13} \mathrm{C}$ NMR of different tannins and models. J Appl Polym Sci 55:1265-1269

Pizzi A, Stephanou A (1993a) Rapid curing lignins-based exterior wood adhesives, part 2: acceleration mechanisms and application to panel products. Holzforschung 47:501-506

Pizzi A, Stephanou A (1993b) Comparative and differential behaviour of pine vs. pecan nut tannin adhesives for particleboard. Holzforschung Holzverwertung 45:30-33

Pizzi A, Stephanou A (1993c) A ${ }^{13}$ C NMR study of polyflavonoid tannin adhesives intermediates, part 1: non-colloidal, performancedetermining rearrangements. J Appl Polym Sci 50:2105-2113

Pizzi A, Stephanou A (1993d) Rapid curing lignins-based exterior wood adhesives, part 1: diisocyanates reaction mechanisms and application to panel products. Holzforschung 47:439-445

Pizzi A, Walton T (1992) Non-emulsifiable, water-based diisocyanate adhesives for exterior plywood, part 1: novel reaction mechanisms and their chemical evidence. Holzforschung 46:541-547

Pizzi A, Valenzuela J, Westermeyer C (1993) Non-emulsifiables, waterbased, diisocyanate adhesives for exterior plywood, part 2: industrial application. Holzforschung 47:69-72

Pizzi A, Valenzuela J, Westermeyer C (1994) Low-formaldehyde emission, fast pressing, pine and pecan tannin adhesives for exterior particleboard. Holz Roh Werkst 52:311-315

Pizzi A, Meikleham N, Dombo B, Roll W (1995a) Induced accelerated autocondensation of polyflavonoid tannins for phenolic polycondensates - part II: cellulose effect and application. Holz Roh Werkst 53:201-204

Pizzi A, Meikleham N, Stephanou A (1995b) Induced accelerated autocondensation of polyflavonoid tannins for phenolic polycondensates - part II: cellulose effect and application. J Appl Polym Sci 55:929-933

Pizzi A, Roll W, Dombo B (1996) Hitzehärtende bindemittel, European patent EP-B 0648 807; German patent DE 4406825 A1; USA patent $5,532,330$

Pizzi A, Leban J-M, Kanazawa F, Properzi M, Pichelin F (2004) Wood dowels bonding by high speed rotation welding. J Adhes Sci Technol 18:1263-1278
Pizzi A, Tondi G, Pasch H, Celzard A (2008) MALDI-TOF structure determination of complex thermoset networks - polyflavonoid tannin-furanic rigid foams. J Appl Polym Sci 110:1451-1456

Pizzi A, Kueny R, Lecoanet F, Massetau B, Carpentier D, Krebs A, Loiseau F, Molina S, Ragoubi M (2009) High resin content natural matrix-natural fibre biocomposites. Ind Crop Prod 30:235-240

Pizzi A, Mansouri HR, Leban J-M, Delmotte L, Omrani P, Pichelin F (2011) Enhancing the exterior performance of wood linear and rotational welding. J Adhes Sci Technol 25:2717-2730

Pizzi A, Lagel MC, Redl A (2013a) Colles a bois pour la preparation de panneaux de particules. French patent application FR13/02320

Pizzi A, Zhou X, Navarrete P, Segovia C, Mansouri HR, Placentia-Pena MI, Pichelin F (2013b) Enhancing water resistance of welded dowel wood joints by acetylated lignin. J Adhes Sci Technol 27:252-262

Rokicki G, Piotrowska A (2002) A new route to polyurethanes from ethylene carbonate, diamines and diols. Polymer 43:2927-2935

Sauget A, Pizzi A (2014) Tannin-resorcinol-glutaraldehyde and tanninresorcinol-glyoxal resins and flax fibers biocomposite. J Renew Mat in press

Sauget A, Nicollin A, Pizzi A (2013) Fabrication and mechanical analysis of mimosa tannin and commercial flax fibers biocomposites. J Adhes Sci Technol 27:2204-2218

Sauget A, Zhou X, Pizzi A (2014) Tannin-resorcinol-formaldehyde resin and flax fiber biocomposites. J Renew Matter. doi:10.7569/JRM. 2013.634128

Segovia C, Pizzi A (2009) Performance of dowel-welded wood furniture linear joints. J Adhes Sci Technol 23:1293-1301

Segovia C, Renaud A, Pizzi A (2010) Performance of dowel-welded Ljoints for wood furniture. J Adhes Sci Technol 25:1829-1837

Shen KC (1977) Spent sulpite liquor binder for exterior wafer-board. For Prod J 27:32-38

Shen KC (1998) Adhesive composition. Patent convention treaty patent WO 1998037148A3

Shimatani K, Sono Y, Sasaya T (1994) Preparation of moderate temperature setting adhesives from softwood kraft lignin. Holzforschung 48:337-342

Srivastava VK, Pizzi A (2014) Characterisation and preparation of wood/furanic foams. J Renew Mat 2:201-206

Stemmelen M, Pessel F, Lapinte V, Calliol S, Habas JP, Robin JJ (2011) A fully biobased epoxy resin from vegetable oils: from the synthesis of the precursors of thiol-ene reaction to the study of the final material. J Polym Sci A 49:2434-2444

Tasooji M, Tabarsa T, Khazaeian A, Wool RP (2010) Acrylated epoxidized soy oils as an alternative to urea-formaldehyde in making wheat straw particleboard. J Adhes Sci Technol 24:1717-1727

Thebault M, Pizzi A, Fredon E (2013) Synthesis of resins with ozonized sunflower oil and radiata pine tannins. J Renew Matter 1:242-252

Thebault M, Pizzi A, Dumarcay S, Gerardin P, Fredon E, Delmotte L (2014a) Polyurethanes from hydrolysable tannins obtained without using isocyanates. Indus Crop Prod 59:329-336

Thebault M, Pizzi A, Essawy H, Baroum A, Van Asche G (2014b) Isocyanate free condensed tannin-based polyurethanes. Eur Polym J. doi:10.1016/j.eurpolymj.2014.10.022

Thevenon MF, Pizzi A (2003) Polyborate ions influence on the durability of wood treated with non-toxic protein borate preservatives. Holz Roh Werkst 61:457-464

Thevenon MF, Pizzi A, Haluk J-P (1997) Non-toxic albumin and soja protein borates as ground-contact wood preservatives. Holz Roh Werkst 55:293-296

Thevenon MF, Pizzi A, Haluk J-P (1998a) One-step tannin fixation of non-toxic protein borates wood preservatives. Holz Roh Werkst 56:90

Thevenon MF, Pizzi A, Haluk J-P (1998b) Protein borates as non-toxic, wide-spectrum, ground-contact wood preservatives. Holzforschung $52: 241-248$ 
Thevenon MF, Pizzi A, Haluk J-P, Zaremski A (1998c) Normalized biological testing of protein borates wood preservatives. Holz Roh Werkst 56:162

Thevenon M-F, Tondi G, Pizzi A (2009) High performance tannin resinboron wood preservatives for outdoor end-uses. Holz Roh Werkst 67:89-93

Thevenon M-F, Tondi G, Pizzi A (2011) Environmentally friendly wood preservative system based on polymerized tannin resin-boric acid for outdoor applications. Maderas Ci Technol 12:253-257

Tomkinson J (2002) Adhesives based on natural resources. In: Dunky M, Pizzi A, Van Leemput M (eds) Wood adhesion and glued products: wood adhesives. European Commission, Directorate General for Research, Brussels, pp 46-65

Tondi G, Pizzi A (2009) Tannin based rigid foams: characterisation and modification. Indus Crop Prod 29:356-363

Tondi G, Pizzi A, Masson E, Celzard A (2008a) Analysis of gasses emitted during carbonization degradation of polyflavonoid tannin/ furanic rigid foams. Polym Degrad Stab 93:1539-1543

Tondi G, Pizzi A, Olives R (2008b) Natural tannin-based rigid foams as insulation in wood construction. Maderas Ciencia Tecnol 10:219-227

Tondi G, Pizzi A, Pasch H, Celzard A (2008c) Structure degradation, conservation and rearrangement in the carbonization of polyflavonoid tannin/furanic rigid foams - a MALDI-TOF investigation. Polym Degrad Stab 93:968-975

Tondi G, Pizzi A, Pasch H, Celzard A, Rode K (2008d) MALDI-TOF investigation of furanic polymer foams before and after carbonization: aromatic rearrangement and surviving furanic structure. Eur Polym J 44:2938-2943

Tondi G, Fierro V, Pizzi A, Celzard A (2009a) Tannin-based carbon foams. Carbon 47:1480-1492

Tondi G, Oo CW, Pizzi A, Trosa A, Thevenon M-F (2009b) Metal adsorption of tannin-based rigid foams. Indus Crop Prod 29:336-340

Tondi G, Zhao W, Pizzi A, Fierro V, Celzard A (2009c) Tannin-based rigid foams: a survey of chemical and physical properties. Bioresources Technol 100:5162-5169

Tondi G, Pizzi A, Delmotte L, Parmentier J, Gadiou R (2010) Chemical activation of tannin derived carbon foams. Ind Crop Prod 31:327-334

Tondi G, Wieland S, Lemenager N, Petutschnigg A, Pizzi A, Thevenon M-F (2012a) Efficacy of tannins in fixing boron in wood: fungal and termite resistance. Bioresources 7:1238-1252
Tondi G, Wieland S, Wimmer T, Thevenon MF, Pizzi A, Petutschnigg A (2012b) Tannin-boron preservatives for wood buildings: mechanical and fire properties. Eur J Wood Prod 70:689-696

Trosa A, Pizzi A (1998) Industrial hardboard and other panels binder from waste lignocellulosic liquors/phenol-formaldehyde resins. Holz Roh Werkst 56:229-233

Trosa A, Pizzi A (2001) A no-aldehyde emission hardener for tanninbased wood adhesives. Holz Roh Werkst 59:266-271

Valenzuela J, von Leyser E, Pizzi A, Westermeyer C, Gorrini B (2012) Industrial production of pine tannin-bonded particleboard and MDF. Eur J Wood Prod 70:735-740

Viikari L, Hase A, Quintus-Leina P, Kataja K, Tuominen S, Gadda L (1999) Lignin-based adhesives for particleboard manufacture. European Patent EP 0953029 A1

Wescott JM, Frihart CR, Lorenz L (2006) Durable soy-based adhesives. Proceedings Wood Adhesives 2005, Forest Products Society, Madison, Wisconsin

Wool RP, Sun XS (2005) Bio-based polymers and composites. Academic Press-Elsevier, Amsterdam

Wool RP, Kusefoglu SH, Khot SN, Zhao R, Palmese G, Boyd A, Williams G (1998) Affordable bio-derived plastics and binders for the composite industry. Proceedings 2nd European Panel Products Symposium, Bangor, Wales

Zhang YF, Zeng XR, Ren BY (2009) Synthesis and structural characterization of urea-isobutyraldehyde-formaldehyde resins. J Coat Technol Res 6:337-344

Zhang J, Chen H, Pizzi A, Li Y, Gao Q, Li J (2014) Characterisation and application of urea-formaldehyde-furfural co-condensed resins as wood adhesives. Bio Resources 9:6267-6276

Zhong Z, Sun XS, Wang D, Ratto JA (2003) Wet strength and water resistance of modified soy protein adhesives and effects of drying treatment. J Polym Environ 11:137-144

Zhou X, Pizzi A (2013) Tannin-resorcinol-aldehyde cold-set wood adhesives with only formaldehyde as hardener. Eur J Wood Prod. doi:10. 1007/s00107-013-0701-8

Zhou X, Pizzi A (2014) Pine tannin adhesives for plywood. Int Wood Prod J 5:27-32

Zhou X, Pizzi A, Sauget A, Nicollin A, Li X, Celzard A, Pasch H, Rode K (2013) Lightweight tannin foam/composites sandwich panels and the cold-set tannin adhesive to assemble them. Ind Crops Prod 43: $255-260$ 